\title{
Chemical Diversity and Biological Properties of Secondary Metabolites from Sea Hares of Aplysia Genus
}

\author{
Renato B. Pereira, Paula B. Andrade and Patrícia Valentão *
}

REQUIMTE/LAQV, Laboratory of Pharmacognosy, Department of Chemistry, Faculty of Pharmacy, University of Porto, R. Jorge Viterbo Ferreira No. 228, 4050-313 Porto, Portugal; ren.pereira@gmail.com (R.B.P.); pandrade@ff.up.pt (P.B.A.)

* Correspondence: valentao@ff.up.pt; Tel.: +35-122-042-8653; Fax: +35-122-609-3390

Academic Editor: Anake Kijjoa

Received: 23 December 2015; Accepted: 5 February 2016; Published: 19 February 2016

\begin{abstract}
The marine environment is an important source of structurally-diverse and biologically-active secondary metabolites. During the last two decades, thousands of compounds were discovered in marine organisms, several of them having inspired the development of new classes of therapeutic agents. Marine mollusks constitute a successful phyla in the discovery of new marine natural products (MNPs). Over a 50-year period from 1963, 116 genera of mollusks contributed innumerous compounds, Aplysia being the most studied genus by MNP chemists. This genus includes 36 valid species and should be distinguished from all mollusks as it yielded numerous new natural products. Aplysia sea hares are herbivorous mollusks, which have been proven to be a rich source of secondary metabolites, mostly of dietary origin. The majority of secondary metabolites isolated from sea hares of the genus Aplysia are halogenated terpenes; however, these animals are also a source of compounds from other chemical classes, such as macrolides, sterols and alkaloids, often exhibiting cytotoxic, antibacterial, antifungal, antiviral and/or antifeedant activities. This review focuses on the diverse structural classes of secondary metabolites found in Aplysia spp., including several compounds with pronounced biological properties.
\end{abstract}

Keywords: mollusks; sea hares; Aplysia; secondary metabolites; biological properties

\section{Introduction}

Marine natural products (MNPs) have attracted increasing research attention during the last two decades [1,2]. To date, over 25,000 new compounds from marine organisms have been reported and characterized, most of them exhibiting a wide range of biological activities, playing an important role in the discovery of leads for the development of drugs for the treatment of human diseases [3]. It is estimated that approximately $56 \%$ of the new active marine natural products present anti-cancer activity, followed by $13 \%$ with antibacterial properties [4]. As reported by $\mathrm{Hu}$ [5], approximately $75 \%$ of the compounds were isolated from marine invertebrates, such as mollusks, sponges and echinoderms. Among the Mollusca phylum, 116 genera in particular contributed to the discovery of new compounds over a 50-year period from 1963 [2,6]. Indeed, 18 marine mollusk-derived compounds presenting anti-cancer properties are in phase I, II or III of drug development [7]. One example is dolastatin 10, an antineoplastic peptide first obtained from the Indian Ocean sea hare Dolabella auricularia Lightfoot [8] and later found to be a product of the gastropod's cyanobacterial (Symploca sp.) diet [9,10]. In 2011, brentuximab vedotin (Adcetris ${ }^{\circledR}$ ), an antibody-dolastatin 10 conjugate, was approved by the FDA for the treatment of Hodgkin's lymphoma [11,12]. 
Sea hares are considered as shell-less mollusks, as they have only a degenerated shell in their mantle cavity, exposing their naked and soft bodies to the surroundings [13]. The absence of a shell as physical protection is compensated by several behavioral, anatomical and physiological adaptations $[13,14]$. However, the effective defense mechanism displayed by these organisms is the chemical and behavioral one, releasing a purple ink and opaline when attacked by predators $[13,15,16]$. These secretions contain some bioactive molecules acting by different mechanisms, such as feed stimulants (e.g., taurine), feed deterrents, and aversive compounds [6,13]. Among all mollusks, the sea hares of the Aplysia genus are the most studied by the MNP chemists [2,6]. According to the World Register of Marine Species (WoRMS) database [17], this genus includes 36 valid species and yielded, until 2011, 58 new natural products, Aplysia dactylomela Rang being the source of almost half of them [6,18]. Aplysia sea hares are herbivorous (feeding predominantly on red algae) with the ability to store sequestered bioactive algal metabolites in a specialized digestive gland $[6,19]$. However, the compounds isolated from Aplysia sea hares are either algal natural products obtained from the diet and slightly modified derivatives of them, or they are made de novo by direct synthesis [20].

The first approach on secondary metabolites of a shell-less gastropod dates back to 1963, when Yamamura and Hirata isolated different sesquiterpenes from specimens of Aplysia kurodai Baba [21]. In 2006, Kamiya and co-authors briefly reviewed some bioactive molecules from sea hares [22]. Since then, a huge number of molecules have been discovered, especially from sea hares of the Aplysia genus. More recently, two articles appeared establishing the fatty acid [23] and carotenoid [24] composition of different Aplysia sea hares by GC-MS and LC-DAD, respectively. However, the current review emphasizes the secondary metabolites effectively isolated from sea hares of the Aplysia genus and their biological properties. For this purpose, the compounds were systematized according to their chemical class in macrolides, $\mathrm{C}_{15}$-acetogenins, sterols, monoterpenes, sesquiterpenes, diterpenes and triterpenes, among other metabolites.

\section{Macrolides}

Most macrolides are known as a group of broad-spectrum antibiotics used in the treatment of common bacterial and fungal infections. Some of them, especially from marine sources, have been reported as interesting anti-cancer agents [25]. Marine macrolides are characterized by a highly oxygenated polyene backbone and a macrocyclic lactone [26]. The discovery of these typical structures in sea hares of the Aplysia genus started in 1993, when Yamada and collaborators [27] isolated aplyronines A-C (1-3) (Figure 1) from the fractionation of a lipophilic extract of A. kurodai collected on the Pacific coast of Mie Prefecture (Japan). Aplyronine A (1), as well as its congeners aplyronines B (2) and C (3), proved to be in vitro potent antitumor substances, displaying $\mathrm{IC}_{50}$ values of $0.45,2.9$ and $22 \mathrm{nM}$ against a human cervical carcinoma cell line (HeLa $\left.\mathrm{S}_{3}\right)$, respectively [28]. Aplyronine A (1) proved to be much more cytotoxic than aplyronine C (3), a derivative of 1 lacking the C-7 trimethylserine ester moiety [29]. In vivo studies developed by the same group showed that aplyronine A (1) exhibited exceedingly potent antitumor activity in mouse xenograft models (e.g., P388 murine leukemia, Lewis lung carcinoma, Ehrlich carcinoma, CT26 colon carcinoma and B16 melanoma) [27]. Saito et al. [30], aiming to establish the anti-cancer mechanism of aplyronine A (1), studied its ability to interact with actin, the most abundant protein in the eukaryotic cytoskeleton, responsible for the regulation of various cell functions such as muscle contraction, cell mobility and cell division [31]. Results indicated that aplyronine A (1) has an actin-depolymerizing effect, inhibiting the velocity and the degree of actin polymerization by forming a 1:1 complex with monomeric actin. They also suggested that the C24-C34 side-chain (Figure 1) but not the macrolide ring binds to actin to depolymerize the filament [30]. More recent work developed by Kita and collaborators [32] demonstrated that, in addition to the action of the side-chain, the actin-aplyronine A complex synergistically binds to tubulin at very low concentrations, inhibiting tubulin polymerization, and prevents spindle formation and mitosis in tumor cells. The same study showed that aplyronine C (3), which inhibits actin polymerization in vitro to the same extent as aplyronine A (1), does not bind to 
tubulin, explaining the substantial differences in cytotoxicity effects of compound $\mathbf{1}$ and 3 in HeLa $\mathrm{S}_{3}$ cells reported above [27,32,33]. In addition, treatment with aplyronine $\mathrm{A}(\mathbf{1})$ at $1 \mathrm{nM}$ led to potent caspase 3 activation in $\mathrm{HeLa} \mathrm{S}_{3}$ cells, while treatment with aplyronine C (3) did not, even at $100 \mathrm{nM}$ [33].

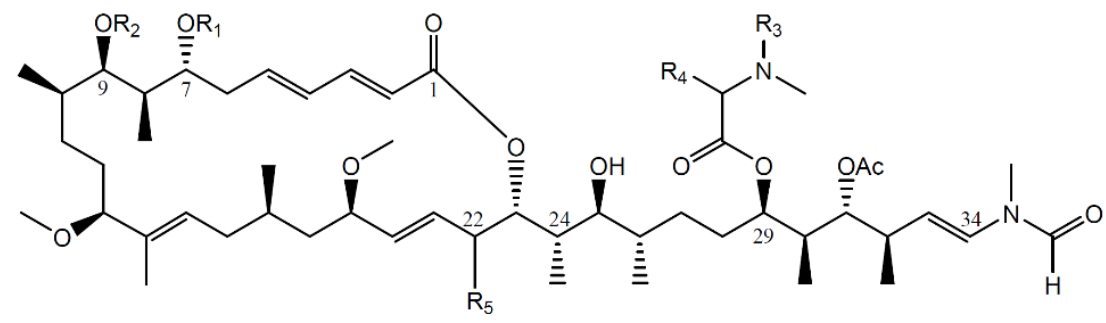

(1)<smiles>[R7][R5]C(=O)C(COC)N(C)C</smiles>
$\mathrm{R}_{3}=\mathrm{CH}_{3} \quad \mathrm{R}_{4}=\mathrm{CH}_{3} \quad \mathrm{R}_{5}=\mathrm{H}$

(2) $\quad \mathrm{R}_{1}=\mathrm{H}$

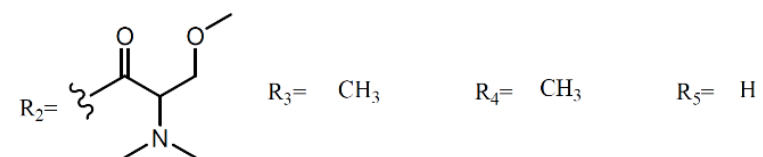

(3) $\quad \mathrm{R}_{1}=\mathrm{H}$

$\mathrm{R}_{2}=\mathrm{H}$

$\mathrm{R}_{3}=\mathrm{CH}_{3}$

$\mathrm{R}_{4}=\mathrm{CH}_{3} \quad \mathrm{R}_{5}=\mathrm{H}$

(4)<smiles>[R7]SC(=O)C(COC)N(C)C</smiles>

$\mathrm{R}_{2}=\mathrm{H}$

$\mathrm{R}_{3}=\mathrm{CH}_{3}$

$\mathrm{R}_{4}=\mathrm{H}$

$\mathrm{R}_{5}=\mathrm{H}$

(5)<smiles>[R]PC(=O)C(COC)N(C)C</smiles>

$\mathrm{R}_{2}=\mathrm{H}$

$\mathrm{R}_{3}=\mathrm{CH}_{3}$

$\mathrm{R}_{4}=\mathrm{CH}$

$\mathrm{R}_{5}=\mathrm{CH}_{3}$

(6)<smiles>[R7]SC(=O)C(COC)N(C)C</smiles>

$\mathrm{R}_{2}=\mathrm{H}$

$\mathrm{R}_{3}=\mathrm{H}$

$\mathrm{R}_{4}=\mathrm{CH}_{3}$

$\mathrm{R}_{5}=\mathrm{H}$

(7)<smiles>[R][As]C(=O)C(COC)NC</smiles>

$\mathrm{R}_{2}=\mathrm{H}$

$\mathrm{R}_{3}=\mathrm{CH}_{3}$

$\mathrm{R}_{4}=\mathrm{CH}_{3}$

$\mathrm{R}_{5}=\mathrm{H}$

(8) $\quad \mathrm{R}_{1}=\mathrm{H}$<smiles>[R7]PC(=O)C(COC)NC</smiles>

$\mathrm{R}_{4}=\mathrm{CH}_{3} \quad \mathrm{R}_{5}=\mathrm{H}$

Figure 1. Structures of aplyronines isolated from A. kurodai.

Aplyronines D-H (4-8), new congeners of aplyronine A (1), were later isolated by Ojika et al. [28] from specimens of $A$. kurodai collected in the same geographical area. The same team also evaluated the cytotoxicity of compounds $\mathbf{4} \mathbf{- 8}$ against $\mathrm{HeLa} \mathrm{S}_{3}$ cells, having obtained $\mathrm{IC}_{50}$ values of $0.075,0.18,0.19$, 0.12 and $9.8 \mathrm{nM}$, respectively [28]. Most of the new congeners showed comparable or higher activity than aplyronine $\mathrm{A}(\mathbf{1})$, indicating that the methylation on the carbon skeleton (C-22) or demethylation in the amino acid moieties (C-7 trimethylserine and C-29 dimethylalanine) enhances or does not affect the cytotoxicity [28].

As such, the C-7 trimethylserine ester moiety of aplyronine A (1) seems to be essential to the interaction with tubulin and in promoting the activation of caspase 3; however, studies involving aplyronines D (4), E (5) and F (6) which also contain the C-7 trimethylserine ester moiety would 
be interesting to confirm this interaction. As compounds 4-7 presented stronger cytotoxicity than aplyronine $\mathrm{A}(\mathbf{1})$, further investigations are required to establish a structural active relationship between the observed cytotoxicity and the binding of these aplyronines to actin/tubulin and the activation of caspase 3.

Aplyolides are unusual molecules belonging to a small group of hydroxyl fatty acid lactones isolated from marine organisms [34]. Aplyolides A-E (9-13) (Figure 2), five unprecedented $C_{16}$ and $C_{18}$ fatty acid lactones, were isolated in 1997 from the external body parts of the sea hare Aplysia depilans Gmelin collected on the Atlantic coast, Asturias (Spain), and the Mediterranean coast, Naples (Italy). The absolute stereochemistry at C-15 was determined by Mosher's method after the opening of the lactone ring [35]. According to the study developed by Spinella et al. [35], the anatomical localization of aplyolides points to their potential biological role as defensive allomones and perhaps to the possibility of the sea hare to biosynthesize these lactones. It is interesting to note that compounds 9-13 were demonstrated to be ichthyotoxic to the mosquito fish Gambusia affinis at 10 ppm, whereas the corresponding methyl esters were completely inactive [35]. Although this group of molecules is associated with interesting biological activities, their paucity precludes more advanced studies.

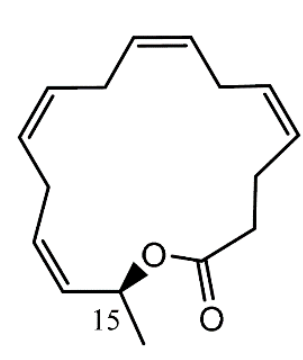

(9)

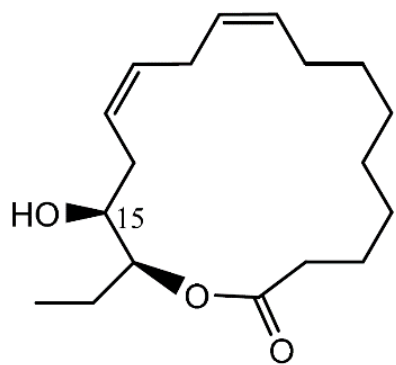

(10)

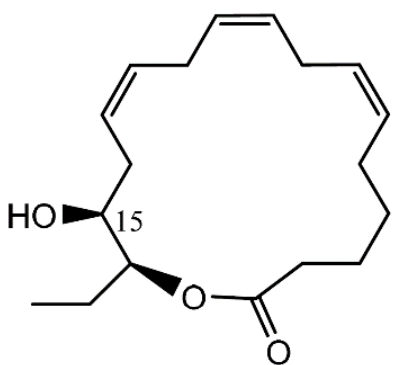

(11)

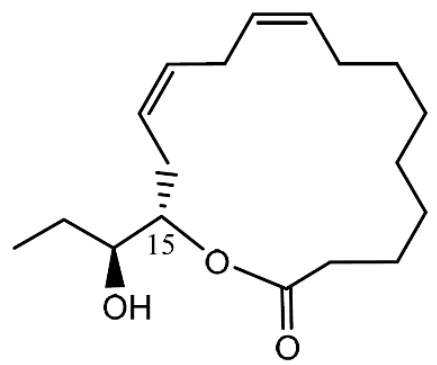

(12)

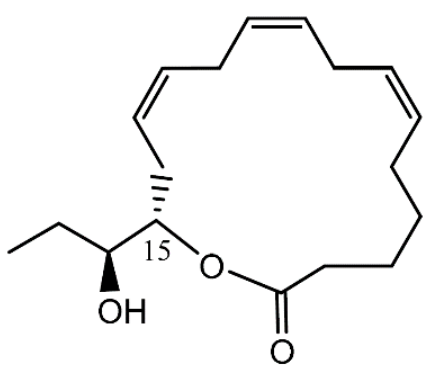

(13)

Figure 2. Structures of aplyolides isolated from Aplysia depilans.

\section{3. $\mathrm{C}_{15}$-Acetogenins}

Many acetogenins, namely $\mathrm{C}_{15}$-halogenated cyclic ethers, have been found in different Aplysia species. Most of these compounds have their origin in algae, especially those from the Laurencia and Plocamium genus, which these mollusks feed $[20,36]$. A number of closely related halogenated cyclic ethers are good inhibitors of drug metabolism, some presenting ichthyotoxic and antifeedant properties [37,38]. The first to be isolated was dactylyne (14) (Figure 3), in 1975, an acetylenic dibromochloro ether from the sea hare A. dactylomela [39]. Three years later, Kaul and Kulkarni [40] studied the pharmacological effect of this drug, demonstrating that it had no direct effect on the cardiovascular, respiratory, and central nervous systems of mice, rats, and guinea pigs. However, in rats, a $25 \mathrm{mg} / \mathrm{kg}$ intraperitoneal dose of dactylyne (14) inhibited pentobarbital metabolism, prolonging sleep time in mice by more than $10 \mathrm{~h}[40,41]$. Its total synthesis was achieved by Gao and Murai in 1992 [42]. Chromatographic separations of the digestive and hermaphroditic glands' organic extract of Aplysia fasciata Poiret led to the isolation of (3Z,9Z)-7-chloro-6-hydroxy-12-oxo-pentadeca-3,9-dien-1-yne (15) 
and (3Z,9Z,12Z)-6-acetoxy-7-chloro-pentadeca-3,9,12-trien-1-yne (16), two linear acetogenins [43] with no bioactivity described until now. Dactylallene (17) was found in the digestive gland of the A. dactylomela mollusk collected in the Canary Islands, Spain. It was revealed to be ichthyotoxic and displayed interesting antifeedant activity, suggesting a defensive role against predators [38]. A $\mathrm{C}_{15}$-acetogenin called laurencenyne (18) was isolated from the ethanol extract of Aplysia punctata Cuvier collected from the northwest coast of Sardinia (Italy) [44]. It was isolated earlier from Laurencia okamurae Yamada and, due to its structure, Kigoshi and collaborators [45] suggested laurencenyne (18) as a possible precursor of various nonterpenoid $\mathrm{C}_{15}$-compounds in the marine red algae of the genus Laurencia. Aplysiallene (19), a new bromoallene targeting $\mathrm{Na}^{+}, \mathrm{K}^{+}$-ATPase, was reported in A. kurodai and collected at the coast of Fukui (Japan) [46]. After being revised, the structure of aplysiallene (19) was found to match that of a bromoallene reported from L. okamurae $[47,48]$.

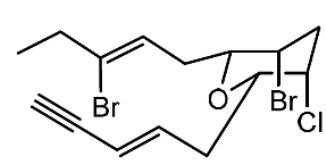

(14)<smiles>C#C/C=C\CC(O)C(Cl)C/C=C/CC(=O)CCC</smiles>

(15)

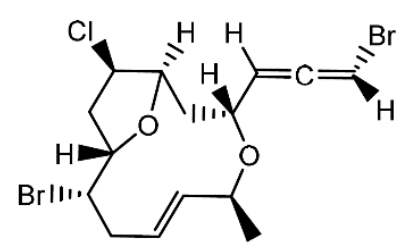

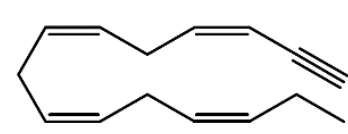

(18)<smiles>C#C/C=C\CC(OC(C)=O)C(Cl)C/C=C/C/C=C/CC</smiles>

(16)

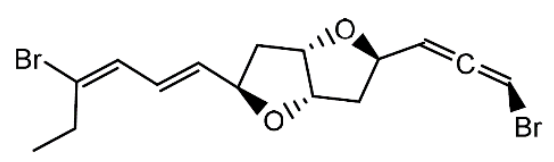

(19)

Figure 3. $C_{15}$-Acetogenins isolated from sea hares of Aplysia genus.

Based on spectroscopic evidence and single-crystal X-ray analysis, Miyamoto et al. [49] elucidated the structure of aplyparvunin (20) (Figure 4), an ichthyotoxic acetogenin isolated from the Japanese marine mollusk Aplysia parvula Mørch. Other eight-membered cyclic ethers, namely (+)-laurenyne (21), (+)-3-E-pinnatifidenyne (22) and (-)-3E,6R,7R-pinnatifidenyne (23), were isolated from a South China Sea collection of the anaspidean mollusk $A$. dactylomela [50]. The (+)-Laurenyne (21) was previously isolated from another sea hare, A. punctata [44], and firstly isolated from the alga Laurencia obtusa (Hudson) Lamouroux [51]. This compound displayed toxicity toward brine shrimp, with an $\mathrm{LC}_{50}$ value of $467.0 \mu \mathrm{M}$ [52]. The (3Z)-13-epi-Pinnatifidenyne (24), an isomer of 22 and 23, was described in the digestive glands of $A$. fasciata [43]. The 3Z-Venustinene (25), a compound containing a novel propyl side-chain without bromine, was firstly isolated from Laurencia venusta Yamada [53] and posteriorly was found by Ioannou and colleagues in studies performed with $A$. fasciata, collected from the Alfacs Bay, Delta de l'Ebre (Spain) [43]. In 2005, McPhail and Davies-Coleman [54] described the isolation of (3Z)-bromofucin (26) from 49 specimens of the cosmopolitan sea hare A. parvula, collected in the Tsistsikamma National Park on the southeast coast of South Africa. It is of note that the majority of the ${ }^{1} \mathrm{H}$ and ${ }^{13} \mathrm{C}$ NMR data of (3Z)-bromofucin (26) were consistent with those of (3E)-bromofucin isolated from Laurencia implicata J.Agardh [55]. The occurrence of similar compounds in Laurencia algae indicated that these species are also the source of (3Z)-bromofucin (26) sequestered by A. parvula from its algal diet. Continuing with the eight-membered cyclic ethers, Kinnel and co-authors [56] described the presence of cis-dihydrorhodophytin (27) and cis-isodihydrorhodophytin (28) in the extract of Aplysia brasiliana Rang (accepted as A. fasciata), compound $\mathbf{2 7}$ behaving as an antifeedant in bioassays with swordtail fish. 


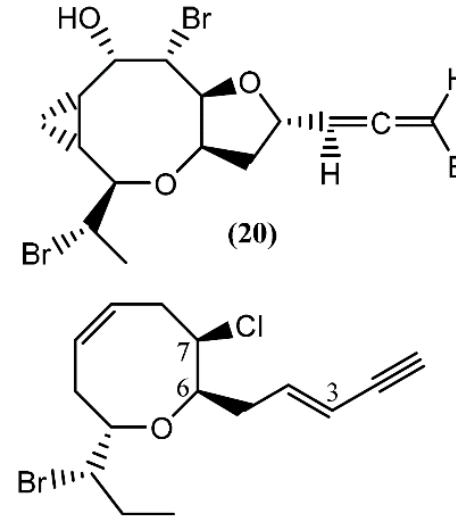

(23)<smiles>C#C/C=C\C[C@H]1C[C@H]2O[C@H](O2)[C@@H](CC)[C@@H](Br)C[C@H]1Br</smiles><smiles>C#C/C=C\C[C@H]1O[C@@H](/C=C/C)C/C=C\C[C@H]1Cl</smiles>

(21)<smiles>C#C/C=C/C[C@@H]1O[C@H]([C@@H](Br)CC)C/C=C\C[C@H]1Cl</smiles>

(22)<smiles>C#C/C=C\C[C@H]1O/C(CCC)=C\C=C/C[C@H]1Cl</smiles>

(25)<smiles>C#C/C=C\C[C@H]1O[C@H]([C@H](Br)CC)C/C=C\C[C@H]1Cl</smiles>

(27)<smiles>C#C/C=C\C[C@H]1O[C@H](C(Br)CC)C/C=C\C[C@H]1Cl</smiles>

(28)

Figure 4. Eight-membered cyclic ether acetogenins isolated from sea hares of Aplysia genus.

Following spectral and X-ray diffraction studies, the same group identified brasilenyne (29) in the same sample (Figure 5), a nine-membered ether ring with fish-feeding deterrent activity [56]. The (+)-3E,6R,7R-Obtusenyne (30) and (+)-3Z,6R,7R-obtusenyne (31), two other halogenated acetogenins containing a nine-membered ether ring, were isolated from $A$. dactylomela [50]. As far as we know, there is no study concerning the bioactivity of these two compounds. More studies regarding the mechanism of action of this class of compounds are necessary for a better understanding of the bioactivities described.<smiles>C#C/C=C\C=C(\Cl)[C@@H]1O[C@H](CC)C=C/C=C\C[C@H]1Cl</smiles>

(29)

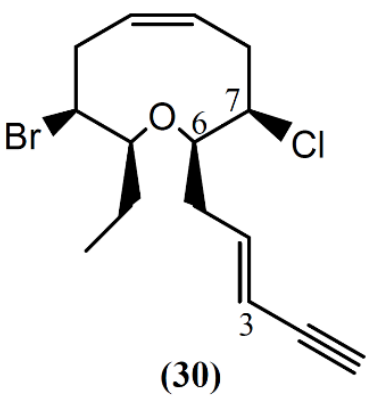

(30)<smiles>C#C/C=C\C[C@H]1O[C@H](CC)[C@@H](Br)C/C=C\C[C@H]1Cl</smiles>

(31)

Figure 5. Nine-membered cyclic ether acetogenins isolated from sea hares of Aplysia genus.

\section{Alkaloids}

Aplysia chemical diversity and richness is also highlighted by the presence of alkaloids. Three prenylated aromatic compounds, aplaminone (32), neoaplaminone (33) and neoaplaminone sulfate (34), were isolated from A. kurodai (Figure 6) [57]. The biogenesis of the aplaminones may be envisaged by coupling a sesquiterpenoid with a brominated dopamine moiety [57]. These compounds are cytotoxic to HeLa $\mathrm{S}_{3}$ cells in vitro, displaying $\mathrm{IC}_{50}$ values of $0.28,1.6 \times 10^{-7}$ and $0.51 \mathrm{mg} / \mathrm{mL}$, respectively [57,58]. Based on the enantioselective synthesis of debromoneoaplaminone, Kigoshi et al. [59] established the absolute stereochemistry of aplaminone (32) and neoaplaminone (33). Another novel alkaloid, aplysepine (35), was isolated from A. kurodai by Ojika et al. [60]. The gross structure was elucidated, aplysepine (35) being the first 1,4-benzodiazepine alkaloid of marine 
origin. Moreover, the pattern of substitution of aplysepine (35) suggested a biosynthetic origin from anthranilic acid and $\beta$-phenylalanine, while other natural benzodiazepines are derived from anthranilic acid and $\alpha$-amino acids. The analysis performed with a single specimen of $A$. dactylomela collected near Leigh Harbour (New Zealand) led to the isolation of dactylamides A and B (36-37) [61], two tryptophan-derived dipeptides with no significant activity reported until now. The absolute stereochemistry of compound $\mathbf{3 6}$ was determined by synthesis of deoxo-diastereomers and comparison of CD spectra [61]. Aplaminal (38) was another alkaloid isolated from a sea hare of the Aplysia genus [62]. This novel triazabicyclo[3,2,1]octane framework metabolite was found in the methanolic extract of A. kurodai and its stereostructure was confirmed by X-ray crystallographic analysis [62]. The 3,7,8-triazabicyclooctane skeleton has not yet been reported in a natural product, although the 1,2,3-triaminopropane framework of aplaminal (38) can be found in tetrahydrofolic acid [62]. According to this, Kuroda et al. [62] suggested a plausible biogenetic pathway for the carbon framework of aplaminal (38), based on the hydrolysis of the guanidine moiety of tetrahydrofolic acid, followed by oxidative cyclization. Compound 38 exhibited cytotoxicity against $\mathrm{HeLa} \mathrm{S}_{3}$ cells, displaying an $\mathrm{IC}_{50}$ of $0.51 \mu \mathrm{g} / \mathrm{mL}$ [62]. Shortly afterwards, the first total synthesis of (-)-aplaminal was achieved in nine steps, with $19 \%$ overall yield [63].<smiles>COc1c(O)cc(CC=C(C)CCCC(C)C(=O)CC=C(C)C)c(CCN(C)C)c1Br</smiles>

(32)<smiles>CNc1cc(CO)c2c(c1OC)NC(c1ccc(O)cc1)CN(C)C2</smiles><smiles>CN(C)C(Cc1c[nH]c2c(O)cccc12)C(=O)N/C=C/c1c[nH]c2ccccc12</smiles><smiles>[R]Oc1cc(CC=C(C)CCCC(C)C(=O)C=CC(C)(C)O)c(CCN(C)C)c(Br)c1OC</smiles>

(34) $\mathrm{R}=\mathrm{OSO}_{3} \mathrm{H}$<smiles>C[NH+](C)[C@H](Cc1c[nH]c2c(O)cccc12)C(=O)N[C@@H](Cc1c[nH]c2ccccc12)C(=O)[O-]</smiles>

(36)<smiles>COC(=O)c1ccc(N2CC3N(C)CC(C(=O)OC)(C2)C3(C)C)cc1</smiles>

Figure 6. Alkaloids isolated from sea hares of Aplysia genus.

\section{Sterols and Degraded Sterols}

In the last decades, sterols from marine organisms such as fungus, macroalgae, sponges, corals and mollusks have shown a panoply of remarkable bioactivities, including antimicrobial [64], cytotoxic [65], antiviral [66], and antibacterial [67]. In the particular case of sterols from sea hares of the Aplysia genus, Jiménez and co-authors [68] described the presence of $5 \alpha, 8 \alpha$-epidioxy sterols (39-41) (Figure 7) in two species: A. depilans and A. punctata. Interestingly, some oxygenated sterols have also been 
reported from the egg masses of Aplysia juliana Quoy \& Gaimard [69]. The endoperoxides (39-41) were isolated from the hepatopancreas (digestive gland) of A. punctata, whereas only compounds 40 and 41 were found in A. depilans [68]. The structure of compound 39 was confirmed by the synthesis from 25-hydroxycholesterol, in a multiple-step reaction [68]. Recently, Mun and colleagues [70] evaluated the cytotoxicity of $5 \alpha, 8 \alpha$-epidioxysterol (39) against human colorectal cancer cells (HCT 116), having obtained an $\mathrm{IC}_{50}$ value of $2.5 \mu \mathrm{M}$. Regarding the bioactivity of $5 \alpha, 8 \alpha$-epidioxycholest-6-en-3 $\beta$-ol (40), Clark et al. [71] discovered antileishmanial properties, displaying an $\mathrm{IC}_{50}$ of $4.9 \mu \mathrm{M}$ towards the amastigote form of Leishmania donovani, but no measurable activity against Plasmodium falciparum, Trypanosoma cruzi, and breast cancer cells (MCF-7).

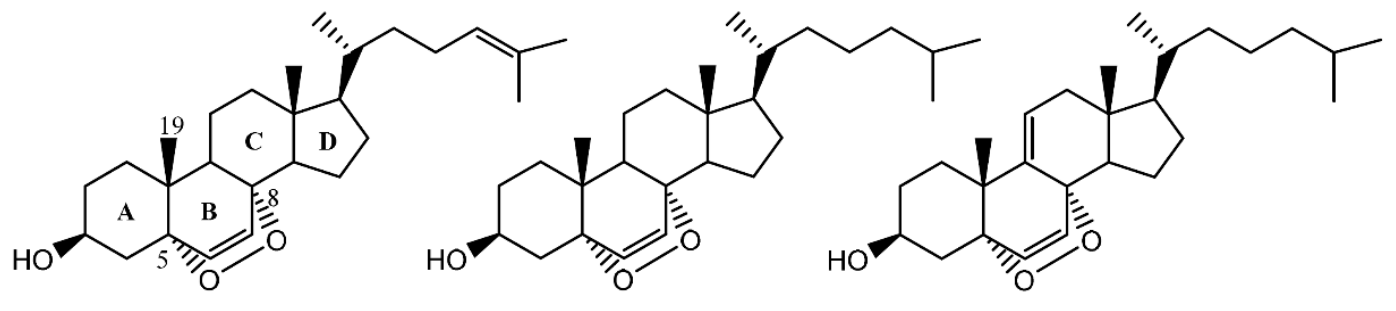

(39)

(40)

(41)

Figure 7. The $5 \alpha, 8 \alpha$-epidioxysterols from sea hares of Aplysia genus.

In addition to these epidioxy sterols, Aplysia mollusks are also known for the presence of families of compounds resulting from the degradation of marine steroids, entitled aplykurodins and aplykurodinones, which showed strong ichthyotoxic and cytotoxic properties [72,73]. The first degraded sterols to be discovered were aplykurodins A and B (42-43) (Figure 8), in A. kurodai [72]. Their carbon skeleton apparently derives from a dramatic oxidative degradation of the tetracyclic steroid nucleus, with the loss of ring-A carbon atoms and of the 19-methyl group (Figure 7) [74]. A very interesting structural feature in aplykurodins is the presence of a cis-hydrindane skeleton. Shoji and colleagues [75] showed that the sterols possessing a cis-C/D ring junction act as powerful inhibitors of histamine release from rat mast cells. In 1992, a study performed with the external parts of the body of $A$. fasciata led to the isolation of two ichthyotoxic lactones: 4-acetylaplykurodin B (44) and aplykurodinone B (45) [73]. Years later, Ortega and co-workers [76] isolated 3-epi-aplykurodinone B (46) from A. fasciata collected in Río San Pedro, Cadiz (Spain). Compound 46 was the last addition to the series, differing from aplykurodinone B (45) by the epimeric relationship at C-3 [76]. It was tested against mouse lymphoma (P-388), human lung carcinoma (A-549), human colon carcinoma (HT-29), and human melanoma (MEL-28) tumor cell lines, exhibiting mild in vitro cytotoxicity (ED 50 of $2.5 \mu \mathrm{g} / \mathrm{mL}$ in all cases) [76].

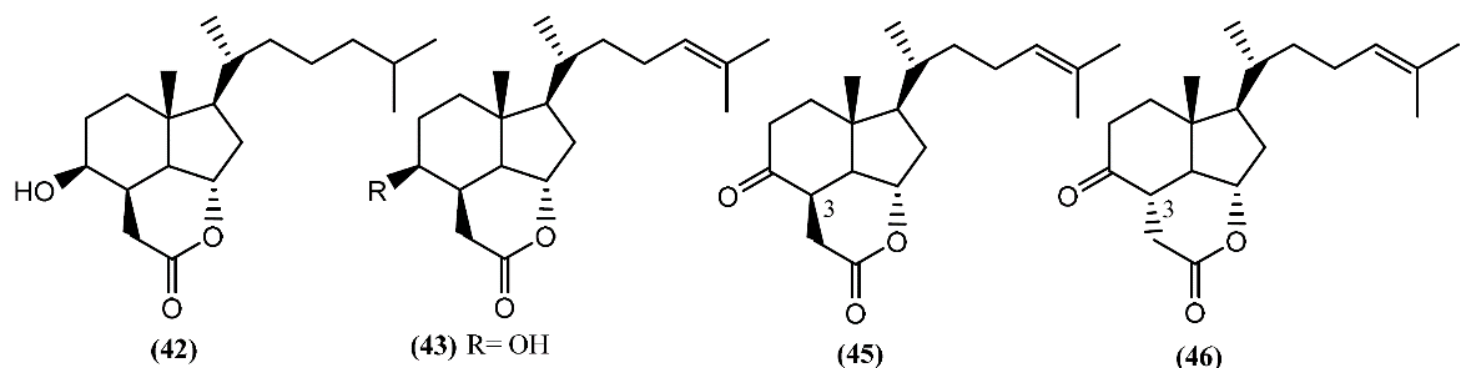

(44) $\mathrm{R}=\mathrm{OAc}$

(46)

Figure 8. Degraded sterols from Aplysia sea hares containing the cis-hydrindane skeleton.

Recently, aplysiasecosterol A (47) (Figure 9), a new 9,11-secosteroid containing an unprecedented tricyclic $\gamma$-diketone structure, was isolated from A. kurodai [77]. A possible biosynthetic pathway 
for the tricyclic $\gamma$-diketone structure, having cholest-7-en-3S,5R,6R-triol as precursor, was suggested, attending to the structural similarity between both the cyclopentane ring and the side-chain part of aplysiasecosterol A (47) and those of known 9,11-secosteroids [77]. Compound 47 did not show significant cytotoxicity against $\mathrm{HeLa}_{3}$ cells at $200 \mu \mathrm{M}$, but it exhibited moderate cytotoxicity against the human myelomonocytic leukemia (HL-60) cell line, displaying an $\mathrm{IC}_{50}$ of $16 \mu \mathrm{M}$ [77]. Furthermore, this was the first molecule having this type of tricyclic ring system, which can be consider as a possible prototype for the synthesis of new analogues with interesting bioactivities.

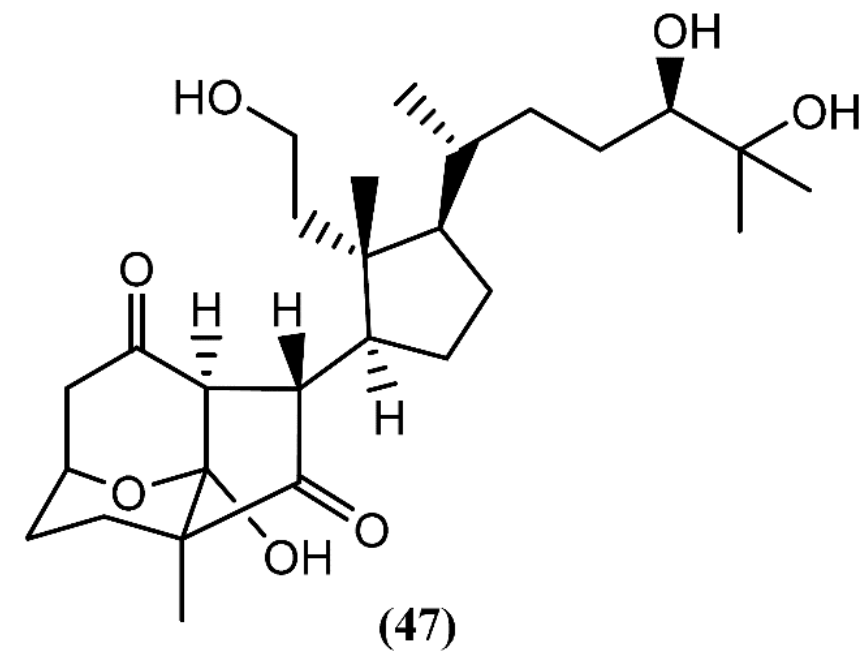

Figure 9. A 9,11-secosteroid from A. kurodai containing a tricyclic $\gamma$-diketone structure.

\section{Terpenoids}

Terpenoids are widespread in algae, marine invertebrates, microorganisms, higher plants, arthropods and fungi [78]. Sea hares have traditionally been a source of terpenoids of dietary origin [79]. The close relationship between the compounds stored in the digestive glands of certain opisthobranchs of the genus Aplysia and the chemical constituents of the algae that form a major portion of their diet has been well established [36]. The genus Aplysia has been extensively studied, affording monoterpenes, sesquiterpenes, diterpenes and triterpenes with varied degrees of halogenation, accumulated from the algal diet and also modified by metabolic transformations [79,80]: the compounds from algae are occasionally chemically transformed by the sea hares [80], frequently being converted into less toxic compounds [81]. This is the main reason why some researchers focus on the study of the digestive gland of sea hares, aiming to discover new molecules to be used in the treatment of several diseases.

\subsection{Monoterpenes}

Halogenated monoterpenes may be linear or cyclic. Generally, Aplysia species are known to yield numerous polyhalogenated monoterpenes, their origin essentially being in red algae of genera Laurencia and Plocamium on which the sea hares feed [82]. Cytotoxicity has been reported for a few marine monoterpenes in the past years. Four cytotoxins, aplysiapyranoids A-D (48-51) (Figure 10), having a halogenated tetrahydropyran, were isolated from the midgut gland of A. kurodai [83]. Compounds 48-51 exhibited moderate cytotoxicity against epithelial-like monkey kidney Vero cells, and Madin-Darby canine kidney (MDCK) and mouse melanoma (B16) cell lines, with $\mathrm{IC}_{50}$ values of 19-96 $\mu \mathrm{g} / \mathrm{mL}$ [83]. Aplysiapyranoid D (51) displayed interesting activity against a human colorectal carcinoma cell line (Moser) $\left(\mathrm{IC}_{50}=14 \mu \mathrm{g} / \mathrm{mL}\right)$ [83]. The total synthesis of aplysiapyranoid A (48), C (50) and D (51) was achieved from simple achiral allylic alcohols by Jung and co-workers [84-86], using a brominative cyclization reaction. Costatone (52), another polyhalogenated pyranoid monoterpene, 
was the main metabolite found in A. parvula [87]. It was previously described in Plocamium costatum (C. Agardh) Hooker \& Harvey, a red algae which served as food for this sea hare [88-91].<smiles>C/C=C/[C@@]1(C)OC(C)(C)[C@@H](Br)C[C@H]1Br</smiles>

(48)<smiles>CC1(C)O[C@](C)(C=CCl)[C@@H](Br)C[C@@H]1Br</smiles>

(49)<smiles>CC1(C)O[C@](C)(/C=C/Cl)[C@H](Cl)C[C@H]1Br</smiles>

(50)<smiles>CC1(C)O[C@](C)(C=CCl)[C@@H](Cl)C[C@H]1Br</smiles>

(51)<smiles>CC(=CCl)[C@@H]1CC(Cl)=C(C)[C@@](O)(C(Br)Br)O1</smiles>

(52)

Figure 10. Pyrano-monoterpenes isolated from sea hares of the Aplysia genus.

The halogenated monoterpenes (53-57) (Figure 11) isolated from Spanish specimens of A. punctata were all traced to the red alga Plocamium coccineum [92]. The $1 R, 2 S, 4 S, 5 R-5-C h l o r o-2(E)$-(chlorovinyl)-1,4-dibromo-1,5-dimethylcyclohexane (55) was also found in three specimens of $A$. dactylomela from San Juan de la Rambla, Tenerife (Spain), together with 4-bromo-5-bromomethyl-2,5-dichloro-1-(E)chloroethenyl-1-methylcyclohexane (58) [82]. Compounds 53 and 58 exhibited activity in a brine shrimp bioassay at $0.5 \mathrm{mg} / \mathrm{mL}$, in the range of $90 \%$ and $100 \%$ lethality after $48 \mathrm{~h}$, respectively [82]. Moreover, compound 58 was weakly cytotoxic towards human lung cancer (Lu1), human oral epidermoid carcinoma (KB), and hormone dependent human breast cancer (ZR-75-1) cells, displaying $\mathrm{IC}_{50}$ values of $12.9,13.3$, and $7.8 \mu \mathrm{g} / \mathrm{mL}$, respectively. It also showed strong algicidal activity against the microalga Chlorella fusca and moderate antimicrobial activities [82]. The cyclic monoterpene aplysiaterpenoid A (59) (Figure 11) and the acyclic monoterpene aplysiaterpenoid B (60) (Figure 12) isolated from A. kurodai exhibited cytotoxic and ichthyotoxic properties [93]. Compound 59 showed mild cytotoxicity against various tumor cell lines, displaying $\mathrm{IC}_{50}$ values of $10 \mu \mathrm{g} / \mathrm{mL}$ for mouse lymphoma (L1210), $15.3 \mu \mathrm{g} / \mathrm{mL}$ for human lung carcinoma (QG-90) and $30.2 \mu \mathrm{g} / \mathrm{mL}$ for human breast cancer (MCF-7) [93]. Moreover, it showed significant ichthyotoxicity against mosquito fish Oryzias latipes and insecticidal activity against the German cockroach Blatella germanica and mosquito larvae Anopheles gambiae [94]. In addition to aplysiaterpenoid B (60), other linear monoterpenes were found in sea hares of the Aplysia genus (Figure 12). The compound 7-Chloro-3,7-dimethyl-1,4,6-tribromo-1-octen-3-ol (61) from Aplysia californica J.G. Cooper was the first of the series [95].<smiles>C[C@]1(Cl)C[C@](C)(Cl)[C@H](Br)C[C@@H]1Br</smiles>

(53)<smiles>C[C@]1(Cl)C[C@](C)(/C=C/Cl)[C@H](Br)C[C@H]1Cl</smiles>

(54)<smiles>C[C@]1(Br)C[C@@](C)(Br)[C@@H](C=CCl)C[C@H]1Br</smiles>

(55)<smiles>C[C@@]1(Cl)C[C@@H](Br)[C@@](C)(/C=C/Br)C[C@H]1Cl</smiles>

(56)<smiles>CC1=C(/C=C/Cl)C[C@H](Br)[C@](C)(Cl)C1</smiles>

(57)<smiles>C[C@]1(/C=C/Cl)C[C@@](Cl)(CBr)[C@@H](Br)C[C@H]1Cl</smiles><smiles>C[C@]1(Cl)C[C@](C)(/C=C/Cl)[C@H](Cl)C[C@@H]1Cl</smiles>

(59)

Figure 11. Cyclic monoterpenes isolated from sea hares of the Aplysia genus. 
<smiles>C[C@@](Cl)(/C=C/[C@@H](Cl)[C@](C)(Cl)/C=C/Br)CCl</smiles>

(60)<smiles>C[C@@](Cl)(CBr)[C@H](O)CC/C(=C/Br)[C@@H](Cl)CBr</smiles>

(63)<smiles>CC(=O)OCCC(C)C(=O)CC/C(=C/Cl)C(Cl)Cl</smiles>

(66)<smiles>CC(C)(Cl)[C@@H](Br)C[C@H](Br)[C@](C)(O)/C=C/Br</smiles>

(61)<smiles>C=C(C)/C=C/C(Cl)=C(\C)CCOC(C)=O</smiles>

(64)<smiles>CC(=O)OCC/C(C)=C(Cl)/C=C/C(C)(Cl)CBr</smiles>

(67)<smiles>C[C@@](Cl)(/C=C/[C@@H](Cl)[C@](C)(Cl)/C=C/Br)C(Br)Br</smiles>

(62)<smiles>CC(=O)OCCC(C)C(=O)CC/C(=C\Cl)C(Cl)Cl</smiles>

(65)<smiles>C[C@@](Cl)(/C=C/Br)[C@H](Cl)/C=C/C(=C\Cl)C(Cl)Cl</smiles>

(68)

Figure 12. Linear monoterpenes isolated from sea hares of the Aplysia genus.

Besides compound 61, one year later, the same group found 3,7-dimethyl-1,8,8-tribromo-3,4,7-trichloro-1,5-octadiene (62) [36,81] in the same species. However, as far as we know, there are no studies concerning to the bioactivity of compounds $\mathbf{6 1}$ and $\mathbf{6 2}$. Kurodainol (63) was found in the gut of A. kurodai, its structure being determined by X-ray analysis [96]. A. punctata from Sancti Petri, Cádiz (Spain), contained four new unusual acetates of linear polyhalogenated monoterpenes (64-67) [97]. It was suggested that these acetates might be biotransformation products [97]. Compounds 65-67 showed identical cytotoxic properties against mice lymphoma (P-388) $\left(\mathrm{ED}_{50}=2.5 \mu \mathrm{g} / \mathrm{mL}\right)$, human lung carcinoma $(\mathrm{A}-549)\left(\mathrm{ED}_{50}=1.5 \mu \mathrm{g} / \mathrm{mL}\right)$, human colon carcinoma (HT-29) $\left(\mathrm{ED}_{50}=2.5 \mu \mathrm{g} / \mathrm{mL}\right)$ and human melanoma (MEL-28) $\left(\mathrm{ED}_{50}=1.5 \mu \mathrm{g} / \mathrm{mL}\right)$ cell lines [97]. Another linear monoterpene, (1E,5E,7E)-1-bromo-7-dichloromethyl-3,4,8-trichloro-octa-1,5,7-triene (68), was isolated from A. dactylomela [82]. Compound 68 demonstrated significant cytotoxicity toward three cancer cell lines (HM02, HEP G2, and MCF 7), displaying $\mathrm{IC}_{50}$ values of $1.1,1.0$ and $1.5 \mu \mathrm{g} / \mathrm{mL}$, respectively [82].

\subsection{Sesquiterpenes}

\subsubsection{Chamigrane Skeleton Sesquiterpenes}

Halogenated chamigrane derivatives are regular sesquiterpenes with a spiro center [98]. Concerning the marine environment, secondary metabolites possessing this skeleton are characteristic of the red algae of the genus Laurencia and of the sea hare grazing on them [20]. Elatol (69), acetylelatol (70), deschlorelatol (71), acetyldeschlorelatol (72) and compound 73 (Figure 13) were isolated from the acetone extract of $A$. dactylomela digestive glands collected from the southwest coast of La Palma Island [99]. Elatol (69) has already displayed a diversity of biological activities, such as parasiticide against the amastigotes of Trypanosoma cruzi and Leishmania amazonensis [100,101], anti-tumor [102], antibacterial against some marine bacteria [103] and larvicidal against the dengue mosquito Aedes aegypti [104]. A recent study developed by Desoti et al. [105] found that the trypanocidal action of (-)-elatol might involve the induction of the autophagic and apoptotic death pathways triggered by an imbalance of the parasite's redox metabolism. The cytotoxic effect of elatol (69) is due to its capacity to induce cell cycle arrest in the $G_{1}$ and the sub- $G_{1}$ phases, leading cells to apoptosis [102]. It is of note that elatol (69) and acetylelatol (70) showed cytotoxic activity against Vero cells, displaying $\mathrm{IC}_{50}$ values of 25 and $44.6 \mu \mathrm{M}$, respectively, while deschloroelatol (71) and its acetyl derivative (72) were inactive [99]. This result indicates the relevance of the chlorine atom and of the free hydroxyl group 
in C-3 of the A-ring to the cytotoxicity toward Vero cells. Moreover, elatol (69) and deschloroelatol (71) exhibited some antifungal properties against Mycotypha microspore and Eurotium repens, with compound 71 being more active [106]. In addition to compound 69, Vairappan and co-authors [107] described the isolation of iso-obtusol (74) from A. parvula, while Díaz-Marrero et al. [108] reported the isolation of the chamigrenes iso-obtusol (74) and obtusol (75) from A. dactylomela. Compound 74 exhibited antibacterial activity against Klebsiella pneumonia and Salmonella sp., equalizing the potency of commercial antibiotics against these two bacteria [109]. Moreover, as compound 69, iso-obtusol (74) also displayed in vitro and in vivo leishmanicidal activity [110]. On the other hand, compound 75 demonstrated significant cytotoxicity toward three cancer cell lines (HM02, HEP G2, and MCF 7) and moderate antimicrobial activity [82]. Recently, another chamigrene, named epi-obtusane (76), has been isolated from an acetone extract of the digestive gland of Aplysia oculifera Adams \& Reeve, showing in vitro cytotoxicity against different human cancer cell lines (PC-3, A549, MCF-7, HepG2 and $\mathrm{HCT} 116)$, with $\mathrm{IC}_{50}$ values in the low $\mu \mathrm{g} / \mathrm{mL}$ range [111]. Continuing with chamigrane sesquiterpenes, Kaiser et al. [112] found prepacifenol and dehydroxyprepacifenol epoxides (77-78) in A. dactylomela collected from Brazilian waters. Prepacifenol epoxide (77) was previously reported in the digestive gland of A. californica [113]. This halogenated sesquiterpene diepoxide seems to be the precursor of johnstonol (79) [114], a chamigrane also found in A. dactylomela from Brazilian waters [115] and in the digestive gland of $A$. californica [36].

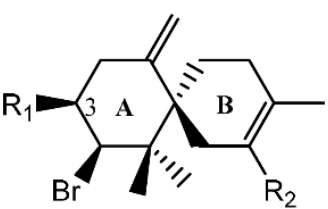

(69) $\mathrm{R}_{1}=\mathrm{OH} \quad \mathrm{R}_{2}=\mathrm{Cl}$

(70) $\mathrm{R}_{1}=\mathrm{OAc} \mathrm{R}_{2}=\mathrm{Cl}$

(71) $\mathrm{R}_{1}=\mathrm{OH} \quad \mathrm{R}_{2}=\mathrm{H}$

(72) $\mathrm{R}_{1}=$ OAc $\mathrm{R}_{2}=\mathrm{H}$

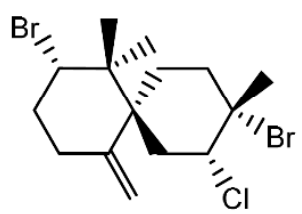

(76)

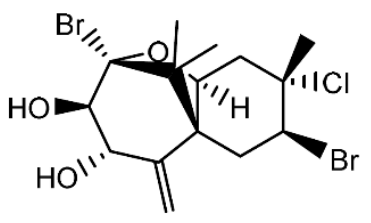

(81)

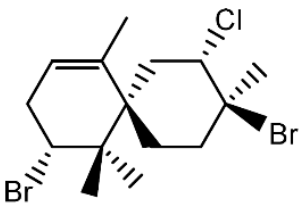

(73)

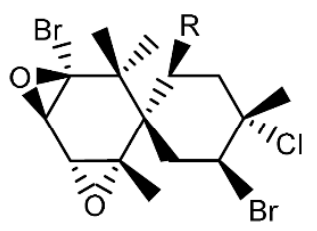

(77) $\mathrm{R}=\mathrm{OH}$

(78) $\mathrm{R}=\mathrm{H}$

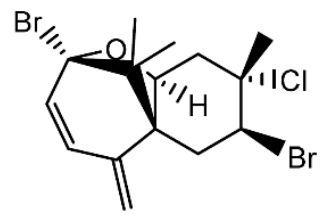

(82)

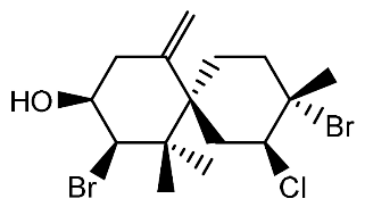

(74)

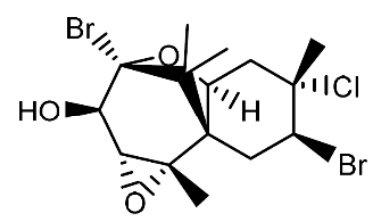

(79)

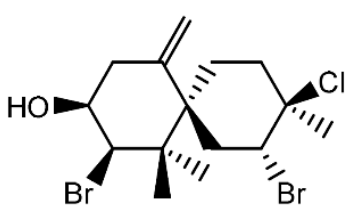

(83)

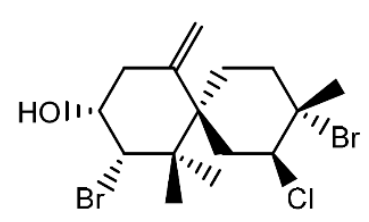

(75)

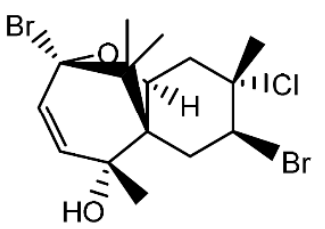

(80)

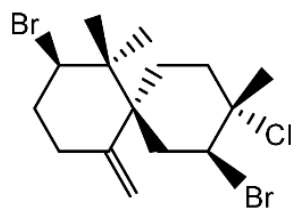

(84)

Figure 13. Chamigrane sesquiterpenes isolated from sea hares of Aplysia genus.

Pacifenol (80), the first natural product described to contain bromine and chlorine, was firstly found in the red algae Laurencia pacifica [116]. Pacifenol (80), together with pacifenediol (81) and pacifidiene (82), was isolated from A. dactylomela in 2001 [117]. Studies exploring the bioactivity of these chamigrenes showed that compound $\mathbf{8 0}$ presented a partial activity against the Gram-negative bacteria Pseudomonas aeruginosa [118] and 90\% of mortality was registered after $24 \mathrm{~h}$ exposure to $23 \mu \mathrm{g} / \mathrm{mL}$ of pacifenol (80) in sea water during the brine shrimp bioassay [119]. Moreover, it is able to decrease the release of eicosanoids, with stronger potency on the cyclooxygenase (COX) pathway [120]. In 2014, Palaniveloo and Vairappan [20] studied the chemical relationship between red algae from the 
genus Laurencia and A. dactylomela from different geographical areas, having found a big diversity of chamigrenes, including rogiolol (83) which had been previously isolated from a Laurencia species [121]. Another study, involving two color variants of $A$. dactylomela, led to the isolation of nidificene (84) [122]. This compound was found to possess antiviral activity against herpes simplex virus-1 (HSV-1), the exo-methylene group being a key factor for the antiviral activity [123].

\subsubsection{Bisabolane and Cuparane Skeleton Sesquiterpenes}

The bisabolane skeleton develops from the cyclization of the geranyl cation and results in the formation of a monocyclic ring structure [124]. This type of compound appears to be among the simplest of sesquiterpenes, because of their structures; however, the bisabolane derivatives isolated from sea hares of the Aplysia genus contain a bicyclic ring structure (Figure 14). Six modified bisabolane sesquiterpenes, caespitane (85), caespitol (86), 8-acetylcaespitol (87), caespitenone (88), laucapyranoid A (89) and furocaespitane (90), were isolated from three distinct samples of A. dactylomela [82]. Compounds 85 and 86 exhibited activity in a brine shrimp bioassay in the range of 100\% lethality within $24 \mathrm{~h}$, dropping to $40 \%$ after $48 \mathrm{~h}$ [82]. Moreover, caespitol (86) displayed algicidal and nematocidal effects toward Caenorrhabditis elegans [82], and very weak cytotoxicity against HeLa 229 cells, presenting an $\mathrm{IC}_{50}$ of $100 \mu \mathrm{g} / \mathrm{mL}$ [125]. It is worth mentioning that small changes in chemical structures can have a pronounced influence on bioactivity. Accordingly, Wessels et al. [82] showed that 8-acetylcaespitol (87), which only differs from caespitol (86) in the acetyl group, was completely inactive in the same assays. Caespitenone (88) is an oxidation product of the algal metabolite caespitol (86) and is probably produced by the animal through the oxidation of the diet-derived natural product [126]. It was found to be active against HT29, MCF7 and A431 cell lines, exhibiting an $\mathrm{IC}_{50}$ of 18.9, 19.7 and $21.6 \mu \mathrm{M}$, respectively [127]. Studies regarding the bioactivity of laucapyranoid A (89) and furocaespitane (90) are necessary to evaluate the influence of the double-bound position in the tetrahydropyran ring and the impact of the furan ring, respectively. Another study with $A$. dactylomela led to the isolation of aplysiadactydiol (91), deschlorobromo caespitol (92), deschlorobromo caspitenone (93) and furocaespitanelactol (94) [128]. The same authors suggested compound 91 as a key intermediate for a unified biogenesis of regular and irregular marine algal bisabolene-type metabolites that are also present in sea hares [128]. Deodactol (95), an antineoplastic sesquiterpene isolated from A. dactylomela, was moderately cytotoxic to the $\mathrm{L} 1210$ cell line, with an ED 50 of $12 \mu \mathrm{g} / \mathrm{mL}$ [129].

Cuparane sesquiterpenes are present in some marine organisms, liverworts and higher plants [130,131]. In those metabolites comprising a cuparane core, carbons 1 and 2 from the aliphatic portion are substituted with a methyl group and dimethyl groups, respectively (Figure 15) [98]. A. dactylomela, collected at the Eastern Cape coast of South Africa, yielded algoane (96), 1-deacetoxyalgoane (97) and 1-deacetoxy-8-deoxyalgoane (98) (Figure 15) [122]. Two other cuparane sesquiterpenes with unprecedented oxygenation patterns, namely cupalaurenol (99) and cupalaurenol acetate (100), were isolated from A. dactylomela [132]. Since cupalaurenol (99) is reported in algae of the Laurencia genus, the acetylation of compound 99 seems to occur inside the sea hare [133]. Compound 99 exhibited potent inhibition against Staphylococcus sp., Staphylococcus aureus, and Salmonella sp., presenting a minimum inhibitory concentration (MIC) of $125 \mu \mathrm{g} / \mathrm{mL}$ for all strains [133]. More recently, oculiferane (101) was isolated from the digestive gland of A. oculifera [111]. Compound 101 showed the same in vitro cytotoxicity reported for epi-obtusane (76), being significantly more active against A549 cells [111]. 


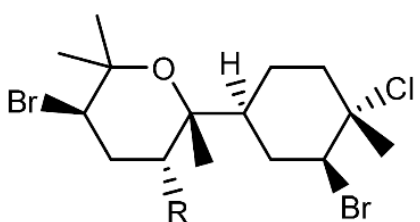

(85) $\mathrm{R}=\mathrm{H}$

(86) $\mathrm{R}=\mathrm{OH}$

(87) $\mathrm{R}=\mathrm{OAc}$<smiles>Cc1occc1[C@H]1CC[C@@](C)(Cl)[C@H](Br)C1</smiles>

(90)

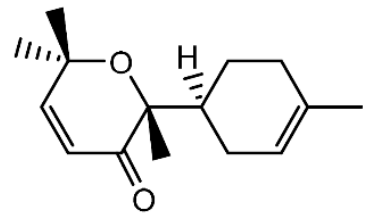

(93)

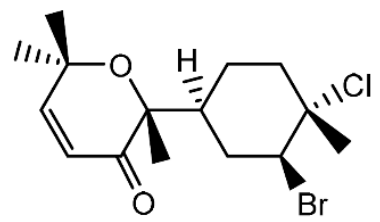

(88)
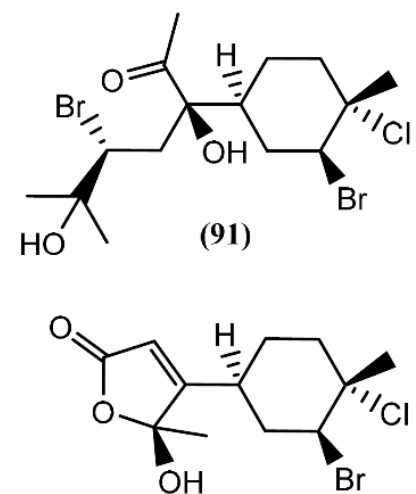

(94)

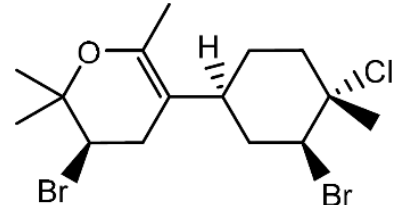

(89)

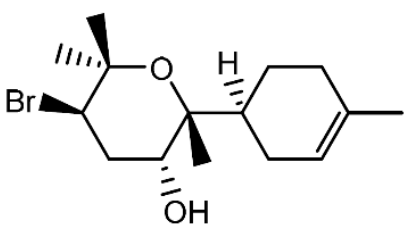

(92)

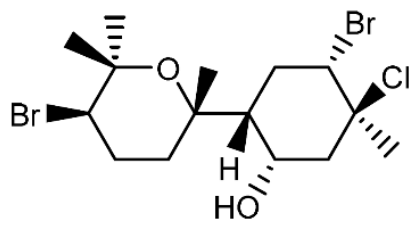

(95)

Figure 14. Bisabolane sesquiterpenes isolated from sea hares of the Aplysia genus.

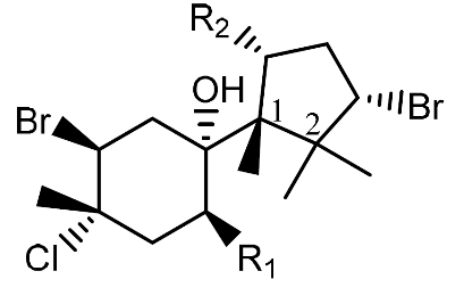

(96) $\mathrm{R}_{1}=\mathrm{OAc} \quad \mathrm{R}_{2}=\mathrm{OH}$

(97) $\mathrm{R}_{1}=\mathrm{H} \quad \mathrm{R}_{2}=\mathrm{OH}$

(98) $\mathrm{R}_{1}=\mathrm{H} \quad \mathrm{R}_{2}=\mathrm{H}$<smiles>[R]c1cc([C@@]2(C)CC=CC2(C)C)c(Br)cc1C</smiles>

(99) $\mathrm{R}=\mathrm{OH}$

(100) $\mathrm{R}=\mathrm{OAc}$<smiles>CC1(C)[C@H](Br)CC[C@@]1(C)[C@]1(O)CC[C@@](C)(Br)[C@H](Cl)C1</smiles>

(101)

Figure 15. Cuparane sesquiterpenes isolated from sea hares of the Aplysia genus.

\subsubsection{Laurane Skeleton Sesquiterpenes}

In Laurane-type compounds, the three methyl groups in the aliphatic portion are located at positions 1, 2 and 3 [98]. The Laurencia genus is considered to be the main producer of laurane-type sesquiterpenes among marine organisms in general. Since Aplysia sea hares feed on this algae, as reported above, it is not strange that this class of compounds is one of the most representative in Aplysia spp. A single specimen of A. dactylomela collected at Kohama Island, Okinawa, provided cyclolaurene (102), cyclolaurenol (103) and cyclolaurenol acetate (104) (Figure 16) [132]. The structures, including their absolute configurations, were elucidated from spectroscopic data and chemical interconversion. Compounds 102-104 displayed antibacterial, antifungal and ichthyotoxic activities [132]. Bioassay-guided purification of the methanolic extract of A. kurodai afforded four active compounds, which were identified as laurinterol (105), laurinterol acetate (106), debromolaurinterol (107), and debromolaurinterol acetate (108) by spectroscopic analysis [134]. Compound $\mathbf{1 0 5}$ had been previously identified by Stallard and Faulkner [36,81] and by Findlay and Li [44] in A. californica and A. punctata, respectively, and it was considered as a promising substance for the prevention and inhibition of melanoma, since it can inhibit the growth of melanoma cells by inducing apoptosis, displaying an 
$\mathrm{IC}_{50}$ of $10 \mu \mathrm{g} / \mathrm{mL}$ [135]. Regarding antibacterial activity, compounds 105 and 107 are more potent than the respective acetates (106 and 108) [134]. Moreover, debromolaurinterol (107), laurinterol (105) and its acetate (106) showed moderate cytotoxicity against HeLa cells, displaying $\mathrm{IC}_{50}$ values of 18, 32 and $20 \mu \mathrm{g} / \mathrm{mL}$, respectively [134]. In 1963, Yamamura and Hirata [21] elucidated the structures of aplysin (109), debromoaplysin (110) and aplysinol (111) isolated from A. kurodai. Aiming to study the effects of compound $\mathbf{1 0 9}$ on the inhibition of gastric cancer, Liu and colleagues [136] showed that it can inhibit the proliferation and induce apoptosis of SGC-7901 cells in vitro. In addition, Gong et al. [137] demonstrated that aplysin (109) can enhance the effect of temozolomide (a chemotherapy drug) on glioma cells by increasing miR-181 expression. According to this, a recent study showed that aplysin (109) can actually induce apoptosis in glioma cells by interference with the HSP90/AKT pathway [138]. Moreover, a toxicological study suggested that aplysin (109) has a significant protective effect on hepatic injury in ethanol-treated rats by modulating the ethanol-metabolizing pathway, attenuating oxidative stress, ameliorating mitochondrial function, and inhibiting mitochondrial damage-mediated apoptosis, which ultimately prevent and repair alcoholic liver injury [139]. Ibhayinol (112) was found in a South African A. dactylomela [122]. Copley et al. [140] established its absolute stereochemistry based on a single-crystal X-ray diffraction experiment.

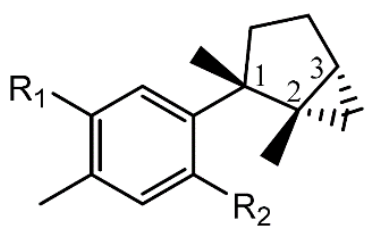

$\begin{array}{ll}\text { (102) } R_{1}=H & R_{2}=H \\ \text { (103) } R_{1}=O H & R_{2}=B r \\ \text { (104) } R_{1}=O A c & R_{2}=B r \\ \left(\mathbf{1 0 5 )} R_{1}=B r\right. & R_{2}=O H \\ \left(\mathbf{1 0 6 )} R_{1}=B r\right. & R_{2}=O A c \\ \left(\mathbf{1 0 7 )} R_{1}=H\right. & R_{2}=O H \\ \text { (108) } R_{1}=H & R_{2}=O A c\end{array}$

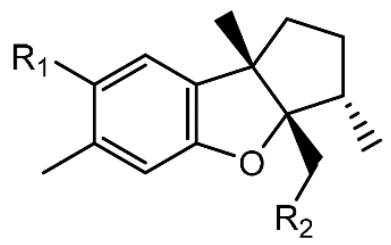

(109) $\mathrm{R}_{1}=\mathrm{Br} \quad \mathrm{R}_{2}=\mathrm{H}$

(110) $\mathrm{R}_{1}=\mathrm{H} \quad \mathrm{R}_{2}=\mathrm{H}$

(111) $\mathrm{R}_{1}=\mathrm{Br} \quad \mathrm{R}_{2}=\mathrm{OH}$

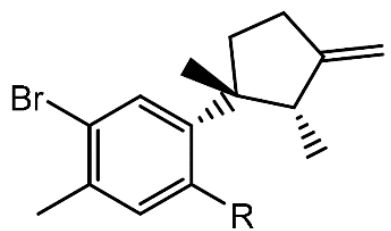

(113) $\mathrm{R}=\mathrm{OH}$

(114) $\mathrm{R}=\mathrm{OAc}$

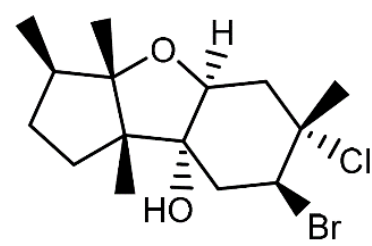

(112)

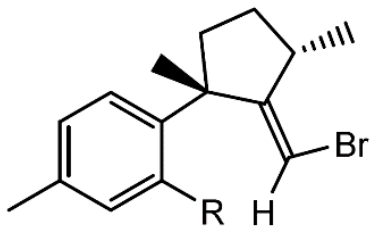

(115) $\mathrm{R}=\mathrm{OH}$

(116) $\mathrm{R}=\mathrm{OAc}$

Figure 16. Laurane sesquiterpenes isolated from sea hares of the Aplysia genus.

Allolaurinterol (113), isolaurenisol (115) and their respective acetates (114 and 116) were isolated from a crude organic extract of $A$. dactylomela, collected near Leigh Harbour, Northland (New Zealand) [61]. Compounds $\mathbf{1 1 3}$ and $\mathbf{1 1 5}$ had previously been reported in Laurencia obtusa and in Laurencia distichophylla, respectively [141,142], but their corresponding acetates $\mathbf{1 1 4}$ and $\mathbf{1 1 6}$ were firstly prepared by synthesis [143]. Appleton and co-authors [61] isolated the acetates from a natural source, indicating that this acetylation probably occurs in the digestive gland of the sea hare. Studies involving the biological activity of these compounds showed that the sesquiterpenes $\mathbf{1 1 3}$ and 115, containing the free phenol group, exhibited moderate P388 and BSC-1 cytotoxicity, also revealing significant antibacterial activity against Bacillus subtilis and moderate activity against the fungus Trichophyton mentagrophytes. On the other hand, the corresponding acetate derivatives (114 and 116) displayed lower P388 cytotoxicity and were less effective against B. subtilis [61].

\subsubsection{Brasilane and Omphalane Skeleton Sesquiterpenes}

The brasilane skeleton has the basic structure of octahydro-1,6,6-trimethyl-4-(1-methyl)-1H-indene [98]. Two non-halogenated sesquiterpenes (Figure 17), brasilenol (117) and brasilenol acetate (118), have been 
isolated along with epibrasilenol (119), from the digestive glands of A. brasiliana collected along the coast of Texas [144]. In addition to these brasilane-type sesquiterpenes, Ioannou and colleagues [43] isolated epibrasilenol acetate (120) and 6-hydroxy-1-brasilene (121) from the organic extract of digestive and hermaphroditic glands of A. punctata. The structure of brasilenols was established by detailed spectral analysis and limited chemical conversions. The methyl, isopropyl, and hydroxyl groups and the tetrasubstituted double bond were defined by spectral analysis [43]. As far as we are aware, the bioactivity of these compounds has not been reported yet.

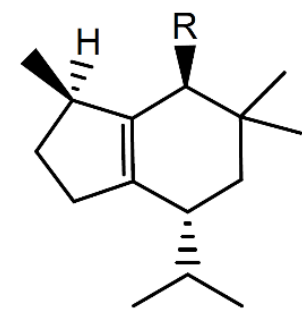

(117) $\mathrm{R}=\mathrm{OH}$

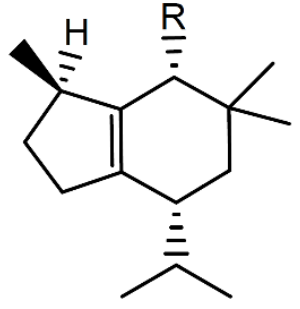

(119) $\mathrm{R}=\mathrm{OH}$

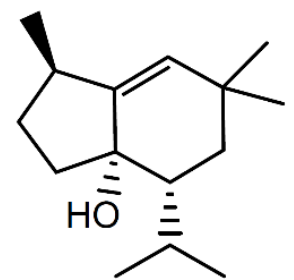

(121)

Figure 17. Brasilane sesquiterpenes isolated from sea hares of the Aplysia genus.

A few years ago, dactylomelatriol (122), the first naturally occurring omphalane-derived sesquiterpene from the marine environment, was extracted from A. dactylomela [108] (Figure 18). This skeleton was encountered for the first time in a liverwort [145] and its structure and relative configuration were established by spectroscopic evidence [108]. According to its structure, Diaz-Marrero and colleagues [108] proposed a biogenetic route, from deschloroelatol (71) until the formation of the rhodolaurane skeleton intermediate, which can undergo a 1,2-shift to generate the omphalane ring system. Compound $\mathbf{1 2 2}$ was tested for its antimicrobial capacity, but revealed to be inactive [108]. However, more studies involving different assays and bioactivities are necessary and could lead to promising results.

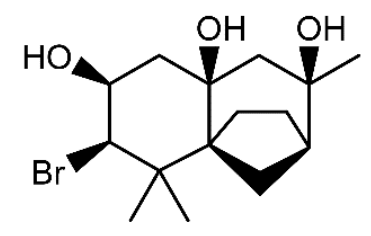

(122)

Figure 18. First marine omphalane-derived sesquiterpene, isolated from A. dactylomela.

\subsubsection{Eudesmane and Snyderane Skeleton Sesquiterpenes}

Eudesmane-type sesquiterpenes (Figure 19), formerly referred to as selinanes, have been recognized in several terrestrial and marine organisms, and occasionally encountered in Aplysia [146]. Two halogenated eudesmanes, brasudol (123) and isobrasudol (124), were found in the digestive gland of $A$. brasiliana from Florida [146]. These brominated eudesmanes have the same absolute configuration of the natural $\beta$-eudesmol and showed feeding-deterrent activity [146]. While compounds $\mathbf{1 2 3}$ and 124 were not reported in the Laurencia genus, other species, such as Laurencia filiformis (C.Agardh) Montagne [147], Laurencia nidifica J.Agardh [148] and Laurencia nipponica Yamada [149], were found to produce similar sesquiterpenes, apparently modified by the sea hares. Later, two antipodal cis-fused eudesmanes, lankalapuol A (125) and B (126), were found in two independent collections of A. dactylomela collected in Hawaii and Sri Lanka [150]. Since the concomitant production of antipodal 
compounds from a single organism is unusual, it was hypothesized that both sesquiterpenes derived from sea hares' algal diet.

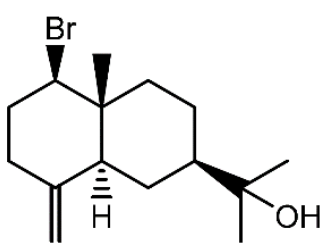

(123)

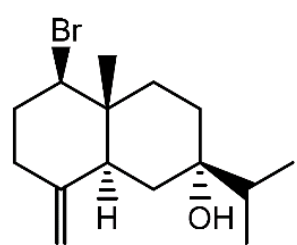

(124)<smiles>CC1=CC[C@@H](Br)[C@]2(C)CC[C@H](C(C)C)[C@H](O)[C@H]12</smiles>

(125)<smiles>C=C1CC[C@@H](Br)[C@]2(C)CC[C@H](C(C)C)[C@H](O)[C@]12C</smiles>

(126)

Figure 19. Eudesmane sesquiterpenes isolated from sea hares of the Aplysia genus.

Snyderane sesquiterpenes are bromo monocyclo-nerolidol derivatives [98]. A collection of A. dactylomela from the Sepanggar Island demonstrated to be a great source of snyderane sesquiterpenes, affording aplysistatin (127), palisadins A (128) and B (129), 5-acetoxypalisadin B (130) and 12-hydroxypalisadin (131) (Figure 20) [151]. The analysis of its diet, namely Laurencia snackeyi (Weber-van Bosse) M.Masuda, showed the presence of these compounds, except 12-hydroxipalisadin (131) [107], suggesting that its biogenesis by hydroxylation of palisadin B (129) probably happens in the gut of the sea hare. The antileukemic agent aplysistatin (127) was firstly isolated from the 2-propanol extract of $A$. angasi [152]. A study regarding the effects of the algal diet on the susceptibility of $A$. parvula to predation indicated that these palisadins appear to be ineffective in the defense against some fishes [153]. However, the three halogenated compounds 127, 128 and 130 exerted profound inhibitory effects on nitric oxide (NO) production by lipopolysaccharide (LPS)-stimulated RAW 264.7 cells [154]. Further experiments demonstrated that, in addition to NO, compound 127 also inhibited prostaglandin-E2 (PGE2) production [154]. This activity was attributed to the modulation of anti-inflammatory agents via the inhibition of nitric oxide synthase (NOS) and cyclooxygenase-2 (COX-2) expression [154].

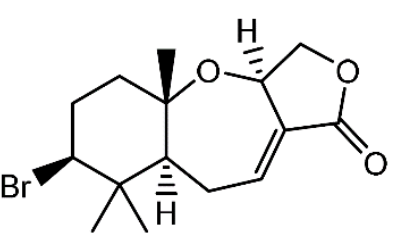

(127)

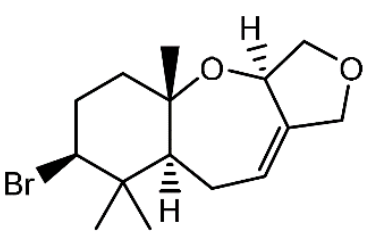

(128)

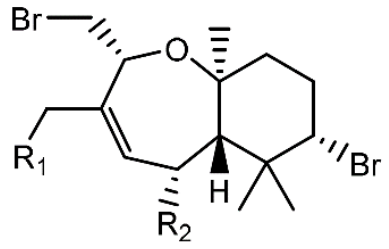

$\begin{array}{ll}\text { (129) } R_{1}=H & R_{2}=H \\ \text { (130) } R_{1}=H & R_{2}=O A c \\ \text { (131) } R_{1}=O H & R_{2}=H\end{array}$

Figure 20. Snyderane sesquiterpenes isolated from sea hares of the Aplysia genus.

\subsection{Diterpenes}

Marine diterpenes have been isolated from both animals and plants. Although red algae of the genus Laurencia mainly produce bromine-containing metabolites with sesquiterpenic skeletons, there are several examples of bromine diterpenes as well. The first halogenated diterpenoid, aplysin-20 (132) (Figure 21), was found in A. kurodai [155]. Further studies on the same species led to the brominated diterpene aplysiadiol (133), together with the methyl ether derivative (134), which contains a rare extended sesquiterpenic skeleton of a prenylated eudesmane [156]. The presence of compound 133 in Aplysia has a probable origin in the diet, as it was also found in the red algae Laurencia japonensis T.Abe \& Masuda [157]. Compound 133 exhibited a potent effect against Staphylococcus sp., S. aureus and Salmonella sp. [133]. Studies involving A. kurodai yielded epi-aplysin-20 (135), an epimer of 132 [158]. 
<smiles>C/C(=C\CO)C[C@]1(O)CC[C@]2(C)[C@@H](C)[C@@H](Br)CC[C@]2(C)[C@H]1C</smiles>

(132)

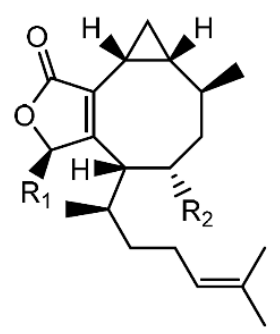

(136) $\mathrm{R}_{1}=\mathrm{H} \quad \mathrm{R}_{2}=\mathrm{OAc}$

(137) $\mathrm{R}_{1}=\mathrm{OH} \quad \mathrm{R}_{2}=\mathrm{OH}$

(138) $\mathrm{R}_{1}=\mathrm{OH} \quad \mathrm{R}_{2}=\mathrm{OAc}$

(139) $\mathrm{R}_{1}=\mathrm{H} \quad \mathrm{R}_{2}=\mathrm{OH}$

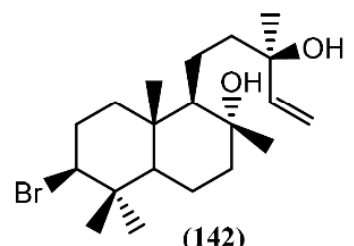<smiles>[R]C(C)(C)/C=C/C=C(\C)[C@@H]1CC[C@@]2(C)[C@H](Br)CCC(=C)[C@@]2(O)C1</smiles>

(133) $\mathrm{R}=\mathrm{OH}$ (134) $\mathrm{R}=\mathrm{OCH}_{3}$

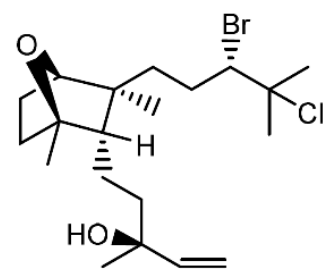

(140)<smiles>C/C(=C\CO)CC[C@@H]1[C@@](C)(O)CC[C@]2(C)C(C)(C)[C@H](Br)CC[C@@]12C</smiles>

(135)<smiles>C=CC(C)(CC[C@H]1[C@H](CCC=C(C)C)[C@H]2CC[C@]1(C)O2)OC(C)=O</smiles>

(141)

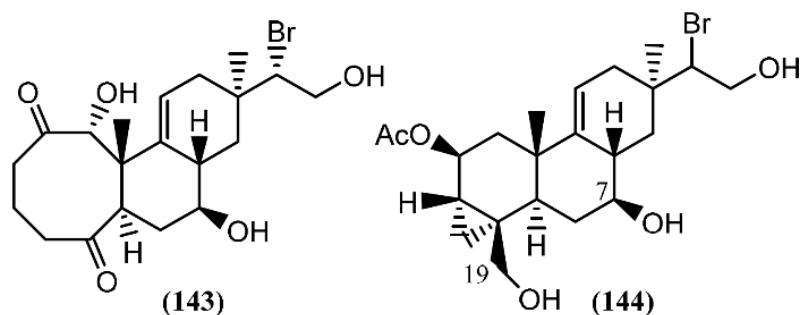<smiles>C=C[C@]1(C)CC[C@H](Br)[C@](C)(CC[C@@H]2C(C)(C)[C@H](Br)CC[C@]2(C)O)O1</smiles>

(145)
(146)

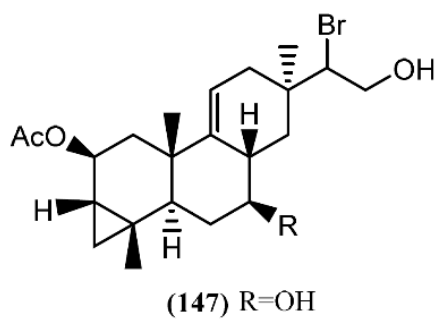

(147) $\mathrm{R}=\mathrm{OH}$

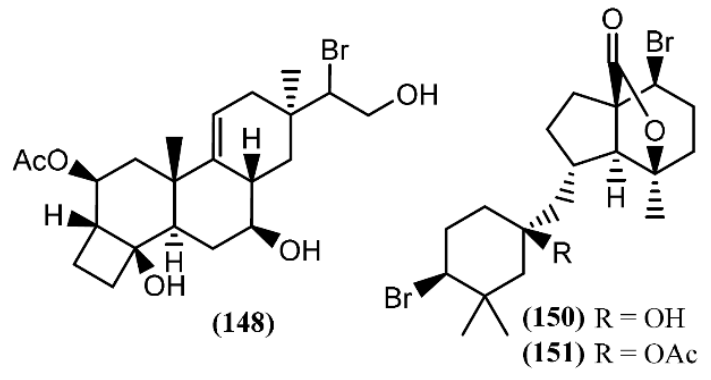<smiles>CC(=O)O[C@H](CC[C@H](C)[C@H]1CCC(C)=C[C@H]1O)[C@@](C)(O)CCC=C(C)C</smiles>

(152)

Figure 21. Diterpenes isolated from sea hares of the Aplysia genus.

Non-halogenated diterpenoids, namely acetoxycrenulide (136), 1,9-dihydroxycrenulide (137), 1-hydroxy-9-acetoxycrenulide (138) and 9-hydroxycrenulide (139), were found in the digestive glands of Pacific Aplysia vaccaria Winkler [159]. This series of crenulides is typical of the brown alga Dictyota crenulata J.Agardh [160]. One of them, acetoxycrenulide (136), is recognized to be highly toxic to the herbivorous reef fish Eupomacentrus leucostictus at very low concentrations (10 $\mu \mathrm{g} / \mathrm{mL})$ [160], and to present anti-microfouling properties against two marine bacterial strains, 4M6 and D41, displaying an $\mathrm{EC}_{50}$ of approximately 69 and $82 \mu \mathrm{M}$, respectively [161]. Moreover, studies regarding the cytotoxicity of compound $\mathbf{1 3 6}$ showed moderate activity against human nasopharynx carcinoma (KB), human lung carcinoma (NSCLC-N6), murine leukemia (P-388), and murine leukemia expressing multi-drug-resistance gene (P-388/DOX) cells [162]. An anti-melanogenesis study demonstrated 
that 1,9-dihydroxycrenulide (137) inhibits melanin synthesis in B16F10 melanoma cells, pointing to a possible therapeutic use in the treatment of hyperpigmentation [163].

A new bicyclic diterpene, dactylomelol (140), was first isolated from A. dactylomela [164] and found afterwards in specimens of Laurencia sp. [165]. Compound $\mathbf{1 4 0}$ exhibited activity in a brine shrimp bioassay in the range of $100 \%$ lethality within $24 \mathrm{~h}$ to $40 \%$ after $48 \mathrm{~h}$ [82]. Since this discovery, another diterpene sharing the same bicyclic system as 140, named punctatene acetate (141), was isolated from A. punctata, together with isoconcinndiol (142), neopargueroldione (143), parguerol (144), deacetylparguerol (145) and punctatol (146) [44]. Parguerol (144) and other two derivatives, deoxyparguerol (147) and isoparguerol (148), were previously found in A. dactylomela [166]. Compounds 144 and 148 induced neurite outgrowth in rat pheochromocytoma PC-12 cells at concentrations of 25 and $50 \mu \mathrm{M}$, respectively [167], pointing to a possible use in the treatment of various neuronal degenerative disorders. It of note that deoxyparguerol acetate (149), isolated from the methanolic extract of $A$. kurodai collected from Toyama Bay in the Japan Sea, did not show the same capacity of parguerol (144), even at a concentration of $100 \mu \mathrm{g} / \mathrm{mL}$ [167], suggesting that the free hydroxyl group at C-7 and/or the presence of the hydroxyl group at C-19 is essential to the reported bioactivity. According to this, an in vitro screening on Ehrlich carcinoma tumor cells demonstrated that isoparguerol (148) is slightly more effective than other parguerol derivatives, while deoxyparguerol derivatives are the least active [168]. In addition, contrary to the effect of acetylation on the neurotrophic activity in PC-12 cells, the acetyl derivatives of these compounds have high cytotoxic activity, the number of acetoxy groups being essential for maximum cytotoxicity [168].

The dibromoditerpene designated angasiol (150) was isolated from a 2-propanol extract of Aplysia angasi G.B. Sowerby II (accepted as A. dactylomela) [169]. Years later, the corresponding acetate (151) was found in A. juliana from the Karachi coastline of the Arabian ocean [170].

Recently, dactyloditerpenol acetate (152), a new regular diterpene possessing an unusual 1,6-anti-3-methylcyclohex-2-en-1-ol ring system, was found in A. dactylomela [171]. Kishi's method was applied to assign the absolute configuration of the hydroxyl groups [171]. In vitro studies involving this prenylbisabolane-type diterpene (152) revealed its potent capacity to inhibit thromboxane $B_{2}$ and the superoxide anion generated in LPS-activated rat neonatal microglia, displaying $\mathrm{IC}_{50}$ values of 0.4 and $1 \mu \mathrm{M}$, respectively [171]. These results are indicators for a possible therapeutic approach to ameliorate neuroinflammatory disorders [172].

\subsection{Triterpenes}

The interest in the biological activity of marine triterpenoids continues, with recent works focusing on their antiviral [173], anti-inflammatory [174], and antitumor [175-177] capacity. Two studies described the isolation of triterpenoids from Aplysia species [178,179]. Aplysiol A (153) and B (154) (Figure 22) are interesting squalene-derived polyethers containing a dioxabicyclo[4,4,0]decane ring, which were isolated together with structurally related metabolites, namely thyrsiferol (155) and venustatriol (156), from a South China Sea collection of A. dactylomela [178]. Posteriorly, Ola et al. [180] and Cen-Pacheco et al. [181] revised the structure of Aplysiol B (154). Compound 155 and the antiviral 156 were previously reported as metabolites of Laurencia thyrsifera J.Agardh [182] and Laurencia venusta [183], respectively. Aplysiol A (153) and B (154) were present on the mantle of the sea hare, suggesting an involvement of these molecules in the chemical defense mechanism of the mollusk. Strongly supporting their possible defensive role, Manzo et al. [178] demonstrated that compounds 153 and 154 were active in the feeding-deterrence test against gold fish Carassius auratus at $50 \mu \mathrm{g} / \mathrm{cm}^{2}$, and were toxic in the ichthyotoxicity assay on G. affinis at a concentration of $10 \mathrm{ppm}$. Thyrsiferol (155) showed a potent and selective activity against P-388 cells, displaying an $\mathrm{IC}_{50}$ of $0.01 \mu \mathrm{g} / \mathrm{mL}$ [184]. It also presented moderate cytotoxicity against A549 and HT29 cells, with an $\mathrm{IC}_{50}$ of $10 \mu \mathrm{g} / \mathrm{mL}$ for both tumor cell lines [184]. Interestingly, degradation studies involving oxidative fragmentation of thyrsiferol (155) produced subunits devoid of significant cytotoxic activity [184]. Moreover, molecular modeling studies have proposed that the presence of the flexible chain around C-14 to C-19 is one of 
the essential factors related to the cytotoxic activity of this compound, whereas the presence or absence of the hydroxyl group at C-15 is indifferent $[184,185]$. More recently, in vitro studies using human breast tumor (T47D) cells showed that thyrsiferol (155) inhibits the activation of hypoxia-inducible factor-1 (HIF-1), a transcription factor with an important role in the etiology and progression of cancer, by interference from various mechanisms, such as the metabolism of anaerobic energy, angiogenesis and drug resistance $[186,187]$. In addition to the cytotoxic activity by apoptosis induction, thyrsiferyl derivatives are also recognized by distinct biological activities, including the selective inhibition of serine/threonine phosphatase $2 \mathrm{~A}$, a protein implicated in cell growth and signaling $[188,189]$.

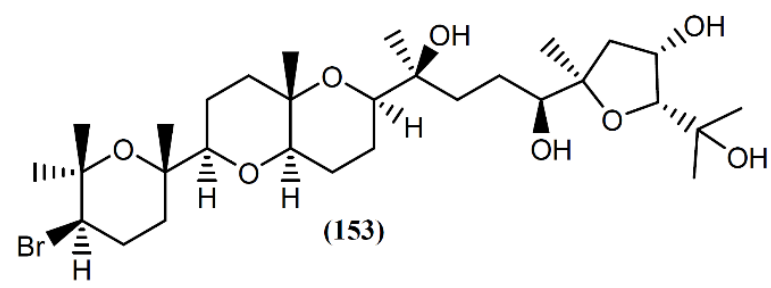

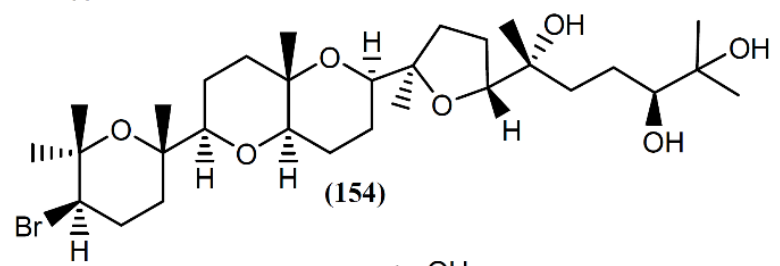

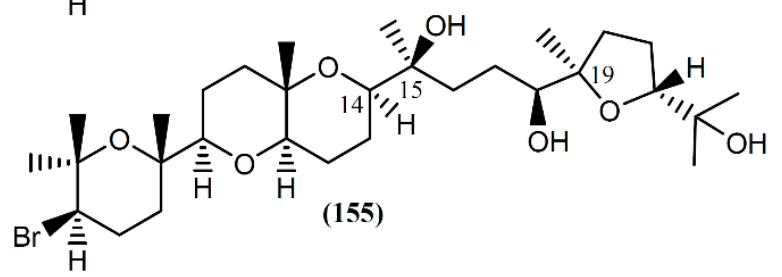

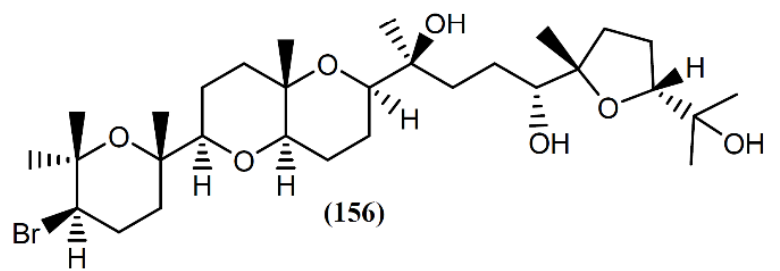

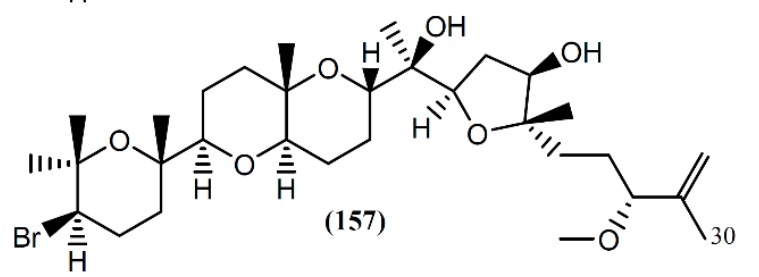

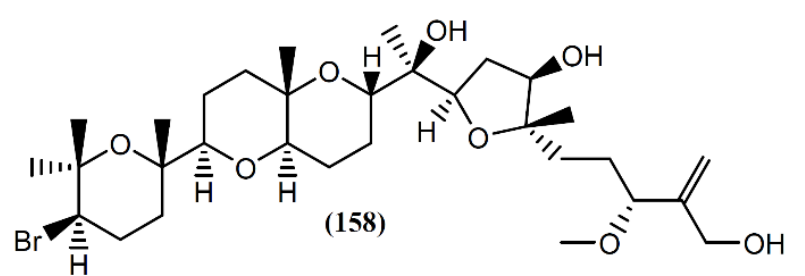

Figure 22. Brominated triterpenes with tetracyclic skeletons isolated from A. dactylomela.

Aplysqualenols A (157) and B (158), brominated triterpenes structurally related to thyrsiferol, were isolated from two specimens of $A$. dactylomela collected in Puerto Rico [179]. A biogenetic pathway for compound 157 was suggested, compound 158 being posteriorly obtained by enzymatic hydroxylation at C-30 [179]. Upon screening by the National Cancer Institute's (NCI's) in vitro antitumor assay, 
containing 60 human tumor cell lines, the squalene-derived polyether $\mathbf{1 5 7}$ exhibited inhibitory activity against SNB-19 Central Nervous System (CNS) cancer cells and T-47D breast cancer cells, with $\mathrm{IC}_{50}$ values of 0.4 and $0.3 \mu \mathrm{g} / \mathrm{mL}$, respectively [179]. Furthermore, aplysqualenol A (157) revealed antiviral properties against herpes simplex virus type 1 (HSV-1) and type 2 (HSV-2), varicella zoster virus (VZV) and human cytomegalovirus (HCMV), and remarkable toxicity against Epstein-Barr virus (EBV), with no accompanying toxicity seen in the host Daudi cells [179]. Regarding antiplasmodial activity, compounds 157 and 158 showed moderate effect toward Plasmodium falciparum, with $\mathrm{IC}_{50}$ values of 11 and $18 \mu \mathrm{g} / \mathrm{mL}$, respectively [179].

\section{Other Metabolites}

A polybrominated diphenyl ether (159) (Figure 23) was detected in the green alga Cladophora fascicularis and isolated from the digestive gland of A. dactylomela [190]. Compound 159 exhibited potent anti-inflammatory properties and antibacterial activity against Escherichia coli, Bacillus subtilis, and Staphylococcus aureus [190].<smiles>COc1c(Br)cc(Br)cc1Oc1ccc(Br)cc1Br</smiles><smiles>[R]NC1C[C@](O)(CO)CC(=NCC(=O)O)C1OC</smiles>

(162) $\mathrm{R}=\mathrm{CH}_{2} \mathrm{CH}(\mathrm{OH}) \mathrm{CH}_{3}$

(163) $\mathrm{R}=\mathrm{CH}_{2} \mathrm{CH}_{3}$

(164) $\mathrm{R}=\mathrm{CH}_{3}$

(165) $\mathrm{R}=\mathrm{CH}_{2} \mathrm{CH}_{2} \mathrm{OH}$

(166) $\mathrm{R}=\mathrm{H}$

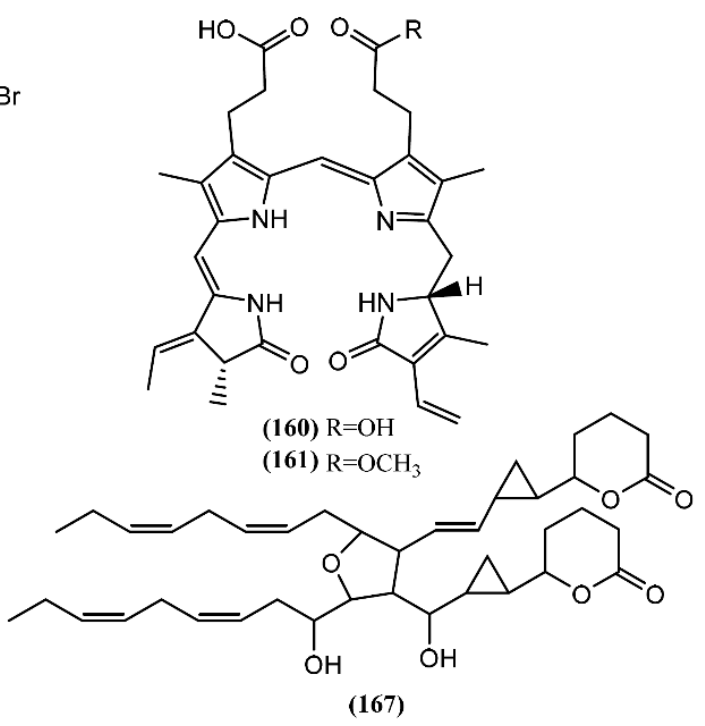

Figure 23. Other metabolites isolated from sea hares of the Aplysia genus.

Bioassay-guided fractionation led to the isolation of two purple molecules, namely phycoerythrobilin (160) and aplysioviolin (161), from the ink of A. californica [191]. Compound 161 was also found in $A$. fasciata, $A$. dactylomela and $A$. parvula $[61,119]$. Sea hares produce compound 160 and 161 from phycoerythrin, a photosynthetic pigment found in their red-alga diet: the cleavage in the digestive gland occurs to generate phycoerythrobilin (160), followed by a methylation in the ink gland to give aplysioviolin (161) [191,192]. Compounds 160 and 161 revealed to be deterrents against predatory blue crabs, being equally effective at $6.25 \mathrm{mg} / \mathrm{mL}$ [192]. This work developed by Kamio and co-authors [192] was the first demonstration of an animal converting a photosynthetic pigment into a chemical defense. It is of note that in vitro assays demonstrated that phycoerythrobilin (160) at $1 \mu \mathrm{mol} / \mathrm{L}$ significantly suppressed IgE antigen-stimulated degranulation of RBL-2H3 cells, while phycoerythrin had no effect [193]. Additionally, the suppression of mast cell degranulation was also observed in rats treated orally with compound 160 at $1 \mu \mathrm{mol} / \mathrm{kg}$, suggesting interesting anti-inflammatory properties [193].

In 2005, HPLC analysis performed by Przeslawski et al. [194] allowed the detection of different mycosporine-like amino acids (MAAs) in egg masses of Aplysia spp. More recently, three new mycosporine-like amino acids (MAAs), namely aplysiapalythines A-C (162-164) were isolated, together with asterina 330 (165) and palythine (166), from opaline, a glandular component of the 
defensive ink secretion of A. californica collected from waters off southern California [195]. The primary mycosporine-glycine is synthesized from 3-dehydroquinate by the shikimate pathway and posteriorly transformed through chemical and/or biochemical conversions into other secondary MAAs [196]. It is important to note that macroalgae, fungi and cyanobacteria biosynthesize MAAs, while animals, such as Aplysia sea hares, which lack the shikimate pathway, acquire these metabolites from their diet or from symbionts [196-198]. Multiple properties are attributed to MAAs, such as the capacity to protect against UV radiation (e.g., MAAs are used in the chemical defense of Aplysia spp. egg masses as potential sunscreens) [194,199-202], and antioxidant [203,204] and osmotic regulation [205]. However, sea hares can modify the function of MAAs: these metabolites are provided from the algae diet, being concentrated in the defensive sea hare secretion, as well as in their skin, functioning as intraspecific alarm cues $[195,197]$.

A particular polyketide with a planar structure, called aplydilactone (167), was isolated from the lipophilic extract of A. kurodai and considered as a new dimeric fatty acid metabolite [190]. According to its molecular structure, Ojika and colleagues [206] suggested that its biosynthesis involves two molecules of eicosapentaenoic acid that undergo unsymmetrical dimerization and oxidative cyclization to form lactones and cyclopropanes [207]. In vitro studies developed by the same group demonstrated that aplydilactone displayed capacity to activate phospholipase A2, an enzyme involved in the inflammatory process [206].

\section{Conclusions}

According to the above information, Aplysia sea hares have provided an important playing field for natural product chemists. To the best of our knowledge, only the species reported in this manuscript have been chemically characterized, these animals being a source of a wide diversity of secondary metabolites with interesting biological properties. Terpenes were the most represented structural class, with more than half of Aplysia secondary metabolites (111 MNPs) (Figure 24A), most of them probably obtained from the algal diet. However, some terpenes can also be a product of the modification of Aplysia dietary compounds. Other algae-related metabolites, namely $\mathrm{C}_{15}$-acetogenins, rate second in proportion (10.78\%). Of the 167 reported molecules, $102(61.08 \%)$ were found to be bioactive. However, this does not mean that the remaining $38.92 \%$ are inactive. Indeed, their bioactivity may be revealed in future studies. Attending to the number of activities attributed to each compound, they can be bi-active, tri-active and tetra-active. As such, and to get a general overlook of the activity spectra of Aplysia spp. molecules, one must count them two, three or four times, respectively. By doing so, seven main bioactivities can be highlighted (Figure 24B), cytotoxicity being the main one.

Indeed, the discovery of particular macrolides, namely aplyronines, was shortly accompanied by strong evidence of their anti-cancer potential and mechanism of action. It is of note that not only macrolides were discovered, but also halogenated terpenoids with cytotoxic, antibacterial, antifungal, antiviral and anti-inflammatory properties.

A closer look at the bioactivity reports within each structural class so far reveals distinct potential (Figure 25). The 13 Aplysia spp. macrolides were all active. Although only $48.65 \%$ of the described terpenes displayed some activity, this seems to actually be the most interesting class because of the large number of metabolites, yielding more candidates for further exploitation.

In general, most of the secondary metabolites found in Aplysia sea hares have displayed interesting in vitro cytotoxic properties, which may provide useful leads for anti-cancer drugs. However, additional pharmacological testing is required to determine whether the cytotoxicity observed for these marine compounds resulted from a specific pharmacologic effect rather than a general toxic effect on the tested cancer cell lines. This should be a prerequisite to understand which molecules may constitute potential drug leads for the treatment of several diseases. 


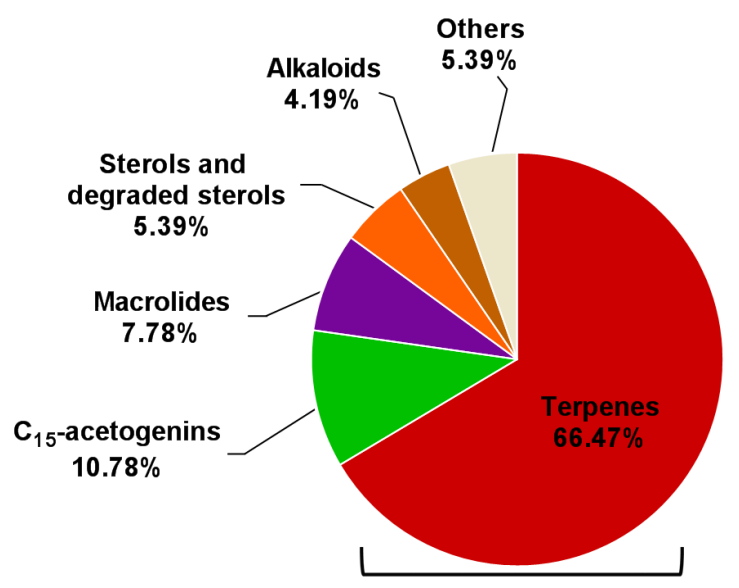

A.
B.

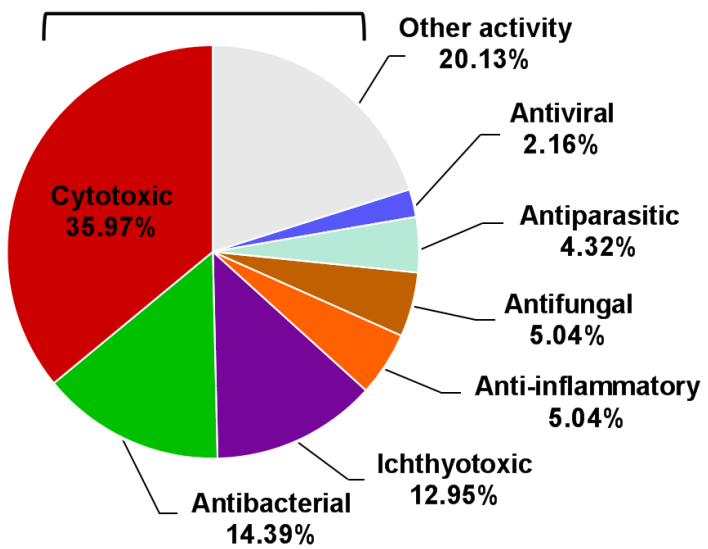

Figure 24. Distribution of compounds described in Aplysia spp. among the several chemical classes (A) and the prevalence of bioactivities attributed to them (B).

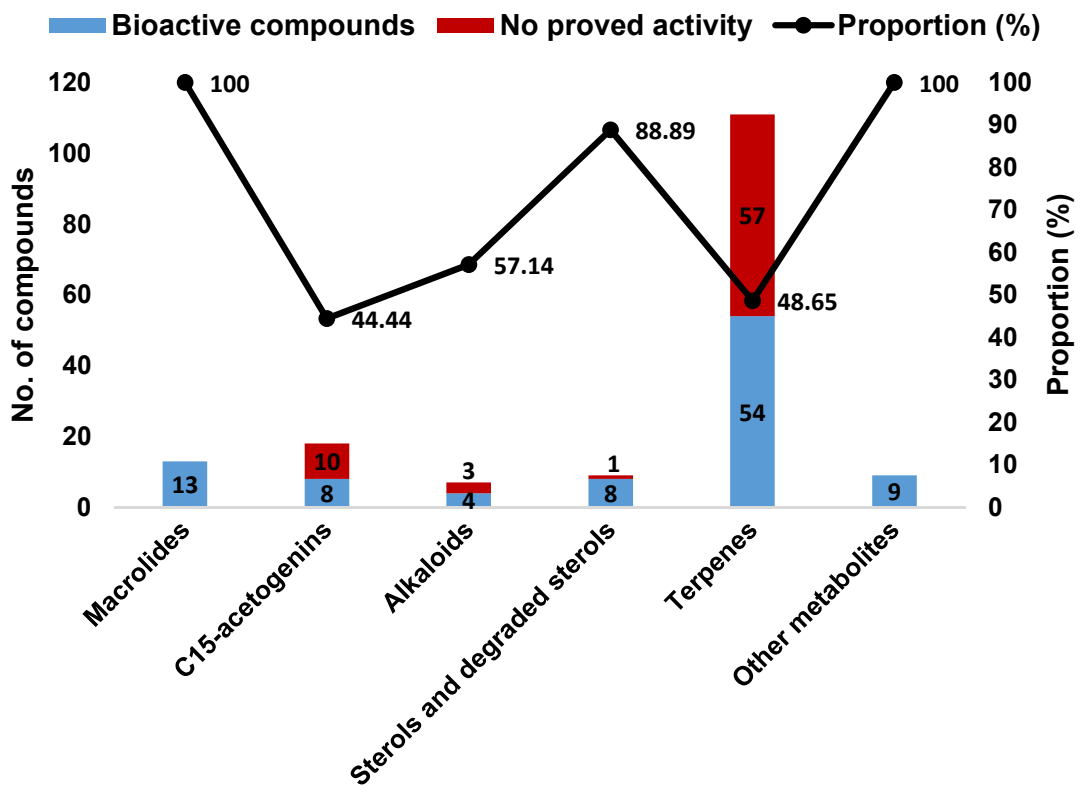

Figure 25. Bioactive compounds from sea hares of the Aplysia genus according to the chemical class.

Acknowledgments: The authors are grateful for the European Union (FEDER funds through COMPETE) and National Funds (FCT, Fundação para a Ciência e Tecnologia) through project UID/QUI/ 50006/2013. R. B. Pereira is grateful to i3DU program for the fellowship (PD/BD/113565/2015).

Conflicts of Interest: The authors declare no conflict of interest.

\section{References}

1. Lebar, M.D.; Heimbegner, J.L.; Baker, B.J. Cold-water marine natural products. Nat. Prod. Rep. 2007, 24, 774-797. [CrossRef] [PubMed]

2. Blunt, J.W.; Copp, B.R.; Keyzers, R.A.; Munro, M.H.; Prinsep, M.R. Marine natural products. Nat. Prod. Rep. 2015, 32, 116-211. [CrossRef] [PubMed]

3. Newman, D.J.; Cragg, G.M. Natural products as sources of new drugs over the 30 years from 1981 to 2010. J. Nat. Prod. 2012, 75, 311-335. [CrossRef] [PubMed] 
4. Hu, Y.; Chen, J.; Hu, G.; Yu, J.; Zhu, X.; Lin, Y.; Chen, S.; Yuan, J. Statistical research on the bioactivity of new marine natural products discovered during the 28 years from 1985 to 2012. Mar. Drugs 2015, 13, 202-221. [CrossRef] [PubMed]

5. Hu, G.P.; Yuan, J.; Sun, L.; She, Z.G.; Wu, J.H.; Lan, X.J.; Zhu, X.; Lin, Y.C.; Chen, S.P. Statistical research on marine natural products based on data obtained between 1985 and 2008. Mar. Drugs 2011, 9, 514-525. [CrossRef] [PubMed]

6. Benkendorff, K. Molluscan biological and chemical diversity: Secondary metabolites and medicinal resources produced by marine molluscs. Biol. Rev. Camb. Philos. Soc. 2010, 85, 757-775. [CrossRef] [PubMed]

7. Martins, A.; Vieira, H.; Gaspar, H.; Santos, S. Marketed marine natural products in the pharmaceutical and cosmeceutical industries: Tips for success. Mar. Drugs 2014, 12, 1066-1101. [CrossRef] [PubMed]

8. Pettit, G.R.; Kamano, Y.; Herald, C.L.; Tuinman, A.A.; Boettner, F.E.; Kizu, H.; Schmidt, J.M.; Baczynskyj, L.; Tomer, K.B.; Bontems, R.J. The isolation and structure of a remarkable marine animal antineoplastic constituent: Dolastatin 10. J. Am. Chem. Soc. 1987, 109, 6883-6885. [CrossRef]

9. Luesch, H.; Moore, R.E.; Paul, V.J.; Mooberry, S.L.; Corbett, T.H. Isolation of dolastatin 10 from the marine cyanobacterium Symploca species VP642 and total stereochemistry and biological evaluation of its analogue symplostatin 1. J. Nat. Prod. 2001, 64, 907-910. [CrossRef] [PubMed]

10. Gerwick, W.H.; Moore, B.S. Lessons from the past and charting the future of marine natural products drug discovery and chemical biology. Chem. Biol. 2012, 19, 85-98. [CrossRef] [PubMed]

11. Newman, D.J.; Cragg, G.M. Marine-sourced anti-cancer and cancer pain control agents in clinical and late preclinical development. Mar. Drugs 2014, 12, 255-278. [CrossRef] [PubMed]

12. Katz, J.; Janik, J.E.; Younes, A. Brentuximab Vedotin (SGN-35). Clin. Cancer Res. 2011, 17, 6428-6436. [CrossRef] [PubMed]

13. Derby, C.D. Escape by inking and secreting: Marine molluscs avoid predators through a rich array of chemicals and mechanisms. Biol. Bull. 2007, 213, 274-289. [CrossRef] [PubMed]

14. Calin-Jageman, R.J.; Fischer, T.M. Behavioral adaptation of the Aplysia siphon-withdrawal response is accompanied by sensory adaptation. Behav. Neurosci. 2007, 121, 200-211. [CrossRef] [PubMed]

15. Love-Chezem, T.; Aggio, J.F.; Derby, C.D. Defense through sensory inactivation: Sea hare ink reduces sensory and motor responses of spiny lobsters to food odors. J. Exp. Biol. 2013, 216, 1364-1372. [CrossRef] [PubMed]

16. Berriman, J.S.; Kay, M.C.; Reed, D.C.; Rassweiler, A.; Goldstein, D.A.; Wright, W.G. Shifts in attack behavior of an important kelp forest predator within marine reserves. Mar. Ecol. Prog. Ser. 2015, 522, $193-201$. [CrossRef]

17. Boxshall, G.A.; Mees, J.; Costello, M.J.; Hernandez, F.; Bailly, N.; Boury-Esnault, N.; Gofas, S.; Horton, T.; Klautau, M.; Kroh, A.; et al. World Register of Marine Species. Available online: http:/ /www.marinespecies. org/aphia.php?p=taxlist (accessed on 27 January 2016).

18. Leal, M.C.; Puga, J.; Serôdio, J.; Gomes, N.C.; Calado, R. Trends in the discovery of new marine natural products from invertebrates over the last two decades-where and what are we bioprospecting? PLoS ONE 2012, 7, e30580. [CrossRef] [PubMed]

19. Pennings, S.C.; Paul, V.J. Sequestration of dietary secondary metabolites by three species of sea hares: Location, specificity and dynamics. Mar. Biol. 1993, 117, 535-546. [CrossRef]

20. Palaniveloo, K.; Vairappan, C.S. Chemical relationship between red algae genus Laurencia and sea hare Aplysia dactylomela Rang in the North Borneo Island. J. Appl. Phycol. 2014, 26, 1199-1205. [CrossRef]

21. Yamamura, S.; Hirata, Y. Structures of aplysin and aplysinol, naturally occurring bromo-compounds. Tetrahedron 1963, 19, 1485-1496. [CrossRef]

22. Kamiya, H.; Sakai, R.; Jimbo, M. Bioactive molecules from sea hares. In Molluscs: From Chemo-Ecological Study to Biotechnological Application; Cimino, G., Gavagnin, M., Eds.; Springer: Berlin, Germany, 2006; pp. 215-234.

23. Pereira, R.B.; Taveira, M.; Valentão, P.; Sousa, C.; Andrade, P.B. Fatty acids from edible sea hares: Anti-inflammatory capacity in LPS-stimulated RAW 264.7 cells involves iNOS modulation. RSC Adv. 2015, 5, 8981-8987. [CrossRef]

24. Oliveira, A.P.; Lobo-da-Cunha, A.; Taveira, M.; Ferreira, M.; Valentão, P.; Andrade, P.B. Digestive gland from Aplysia depilans Gmelin: Leads for inflammation treatment. Molecules 2015, 20, 15766-15780. [CrossRef] [PubMed]

25. Napolitano, J.G.; Daranas, A.H.; Norte, M.; Fernández, J.J. Marine macrolides, a promising source of antitumor compounds. Anticancer Agents Med. Chem. 2009, 9, 122-137. [CrossRef] [PubMed] 
26. Qi, Y.; Ma, S. The medicinal potential of promising marine macrolides with anticancer activity. Chem. Med. Chem. 2011, 6, 399-409. [CrossRef] [PubMed]

27. Yamada, K.; Ojika, M.; Ishigaki, T.; Yoshida, Y.; Ekimoto, H.; Arakawa, M. Aplyronine A, a potent antitumor substance and the congeners aplyronines B and C isolated from the sea hare Aplysia kurodai. J. Am. Chem. Soc. 1993, 115, 11020-11021.

28. Ojika, M.; Kigoshi, H.; Suenaga, K.; Imamura, Y.; Yoshikawa, K.; Ishigaki, T.; Sakakura, A.; Mutou, T.; Yamada, K. Aplyronines D-H from the sea hare Aplysia kurodai: Isolation, structures, and cytotoxicity. Tetrahedron 2012, 68, 982-987. [CrossRef]

29. Kita, M.; Kigoshi, H. Marine natural products that interfere with multiple cytoskeletal protein interactions. Nat. Prod. Rep. 2015, 32, 534-542. [CrossRef] [PubMed]

30. Saito, S.; Watabe, S.; Ozaki, H.; Kigoshi, H.; Yamada, K.; Fusetani, N.; Karaki, H. Novel actin depolymerizing macrolide aplyronine A. J. Biochem. 1996, 120, 552-555. [CrossRef] [PubMed]

31. Yamada, K.; Ojika, M.; Kigoshi, H.; Suenaga, K. Aplyronine A, a potent antitumor macrolide of marine origin, and the congeners aplyronines B-H: Chemistry and biology. Nat. Prod. Rep. 2009, 26, 27-43. [CrossRef] [PubMed]

32. Kita, M.; Hirayama, Y.; Yoneda, K.; Yamagishi, K.; Chinen, T.; Usui, T.; Sumiya, E.; Uesugi, M.; Kigoshi, H. Inhibition of microtubule assembly by a complex of actin and antitumor macrolide aplyronine A. J. Am. Chem. Soc. 2013, 135, 18089-18095. [CrossRef] [PubMed]

33. Kita, M.; Yoneda, K.; Hirayama, Y.; Yamagishi, K.; Saito, Y.; Sugiyama, Y.; Miwa, Y.; Ohno, O.; Morita, M.; Suenaga, K.; et al. Fluorescent aplyronine A: Intracellular accumulation and disassembly of actin cytoskeleton in tumor cells. ChemBioChem 2012, 13, 1754-1758. [CrossRef] [PubMed]

34. Gerwick, W.H. Carbocyclic oxylipins of marine origin. Chem. Rev. 1993, 93, 1807-1823. [CrossRef]

35. Spinella, A.; Zubía, E.; Martînez, E.; Ortea, J.; Cimino, G. Structure and stereochemistry of aplyolides A-E, lactonized dihydroxy fatty acids from the skin of the marine mollusc Aplysia depilans. J. Org. Chem. 1997, 62, 5471-5475. [CrossRef]

36. Stallard, M.O.; Faulkner, D.J. Chemical constituents of the digestive gland of the sea hare Aplysia californica I. Importance of diet. Comp. Biochem. Physiol. B 1974, 49, 25-35. [CrossRef]

37. Kaul, P.N. Compounds from the sea with actions on the cardiovascular and central nervous systems. Fed. Proc. 1981, 40, 10-14. [PubMed]

38. Ciavatta, M.L.; Gavagnin, M.; Puliti, R.; Cimino, G.; Martínez, E.; Ortea, J.; Mattia, C.A. Dactylallene: A novel dietary $C_{15}$ bromoallene from the atlantic anaspidean mollusc Aplysia dactylomela. Tetrahedron 1997, 53, 17343-17350. [CrossRef]

39. McDonald, F.J.; Campbell, D.C.; Vanderah, D.J.; Schmitz, F.J.; Washecheck, D.M.; Burks, J.E.; van der Helm, D. Marine natural products. Dactylyne, an acetylenic dibromochloro ether from the sea hare Aplysia dactylomela. J. Org. Chem. 1975, 40, 665-666. [CrossRef]

40. Kaul, P.N.; Kulkarni, S.K. New drug metabolism inhibitor of marine origin. J. Pharm. Sci. 1978, 67, $1293-1296$. [CrossRef] [PubMed]

41. Kulkarni, S.K.; Kaul, P.N. Substances of marine origin affecting pentobarbital pharmacokinetics. Indian J. Exp. Biol. 1980, 18, 270-272. [PubMed]

42. Gao, L.-X.; Murai, A. Total synthesis of (-)-dactylyne and (-)-isodactylyne. Tetrahedron Lett. 1992, 33, 4349-4352. [CrossRef]

43. Ioannou, E.; Nappo, M.; Avila, C.; Vagias, C.; Roussis, V. Metabolites from the sea hare Aplysia fasciata. J. Nat. Prod. 2009, 72, 1716-1719. [CrossRef] [PubMed]

44. Findlay, J.A.; Li, G. Novel terpenoids from the sea hare Aplysia punctata. Can. J. Chem. 2002, 80, $1697-1707$. [CrossRef]

45. Kigoshi, H.; Shizuri, Y.; Niwa, H.; Yamada, K. Laurencenyne, a plausible precursor of various nonterpenoid $\mathrm{C}_{15}$-compounds, and neolaurencenyne from the red alga Laurencia okamurai. Tetrahedron Lett. 1981, 22, 4729-4732. [CrossRef]

46. Okamoto, Y.; Nitanda, N.; Ojika, M.; Sakagami, Y. Aplysiallene, a new bromoallene as an $\mathrm{Na}^{+}$, $\mathrm{K}^{+}$-ATPase inhibitor from the sea hare, Aplysia kurodai. Biosci. Biotechnol. Biochem. 2001, 65, 474-476. [CrossRef] [PubMed]

47. Suzuki, M.; Kurosawa, E. A $C_{15}$ non-terpenoid from the red alga Laurencia okamurai. Phytochemistry 1985, 24, 1999-2002. [CrossRef] 
48. Wang, J.; Pagenkopf, B.L. First total synthesis and structural reassignment of (-)-aplysiallene. Org. Lett. 2007, 9, 3703-3706. [CrossRef] [PubMed]

49. Miyamoto, T.; Ebisawa, Y.; Higuchi, R. Aplyparvunin, a bioactive acetogenin from the sea hare Aplysia parvula. Tetrahedron Lett. 1995, 36, 6073-6074. [CrossRef]

50. Manzo, E.; Ciavatta, M.L.; Gavagnin, M.; Puliti, R.; Mollo, E.; Guo, Y.-W.; Mattia, C.A.; Mozzarella, L.; Cimino, G. Structure and absolute stereochemistry of novel $\mathrm{C}_{15}$-halogenated acetogenins from the anaspidean mollusc Aplysia dactylomela. Tetrahedron 2005, 61, 7456-7460. [CrossRef]

51. Falshaw, C.P.; King, T.J.; Imre, S.; Islimyeli, S.; Thomson, R.H. Laurenyne, a new acetylene from Laurencia obtusa: Crystal structure and absolute configuration. Tetrahedron Lett. 1980, 21, 4951-4954. [CrossRef]

52. Takahashi, Y.; Daitoh, M.; Suzuki, M.; Abe, T.; Masuda, M. Halogenated metabolites from the new Okinawan red alga Laurencia yonaguniensis. J. Nat. Prod. 2002, 65, 395-398. [CrossRef] [PubMed]

53. Suzuki, M.; Kurosawa, E.; Furusaki, A.; Matsumoto, T. The structures of (3Z)-epoxyvenustin, (3Z)-venustin, and (3Z)-venustinene, new halogenated $C_{15}$-nonterpenoids from the red alga Laurencia venusta Yamada. Chem. Lett. 1983, 5, 779-782. [CrossRef]

54. McPhail, K.L.; Davies-Coleman, M.T. (3Z)-Bromofucin from a South African sea hare. Nat. Prod. Res. 2005, 19, 449-452. [CrossRef] [PubMed]

55. Coll, J.C.; Wright, A.D. Tropical Marine Algae. IV. Novel metabolites from the red alga Laurencia implicata (Rhodophyta, Rhodophyceae, Ceramiales, Rhodomelaceae). Aust. J. Chem. 1989, 42, 1685-1693. [CrossRef]

56. Kinnel, R.B.; Dieter, R.K.; Meinwald, J.; van Engen, D.; Clardy, J.; Eisner, T.; Stallard, M.O.; Fenical, W. Brasilenyne and cis-dihydrorhodophytin: Antifeedant medium-ring haloethers from a sea hare Aplysia brasiliana. Proc. Natl. Acad. Sci. USA 1979, 76, 3576-3579. [CrossRef] [PubMed]

57. Kigoshi, H.; Imamura, Y.; Yoshikawa, K.; Yamada, K. Three new cytotoxic alkaloids, aplaminone, neoaplaminone and neoaplaminone sulfate from the marine mollusc Aplysia kurodai. Tetrahedron Lett. 1990, 31, 4911-4914. [CrossRef]

58. Yamada, K.; Ojika, M.; Kigoshi, H.; Suenaga, K. Cytotoxic substances from two species of Japanese sea hares: Chemistry and bioactivity. Proc. Jpn. Acad. Ser. B 2010, 86, 176-189. [CrossRef]

59. Kigoshi, H.; Adachi, Y.; Yoshikawa, K.; Yamada, K. Absolute stereochemistry of aplaminone and neoaplaminone, cytotoxic bromodopamines from a marine mollusc: Enantioselective synthesis of debromoneoaplaminone. Tetrahedron Lett. 1992, 33, 4195-4198. [CrossRef]

60. Ojika, M.; Yoshida, T.; Yamada, K. Aplysepine, a novel 1,4-benzodiazepine alkaloid from the sea hare Aplysia kurodai. Tetrahedron Lett. 1993, 34, 5307-5308. [CrossRef]

61. Appleton, D.R.; Babcock, R.C.; Copp, B.R. Novel tryptophan-derived dipeptides and bioactive metabolites from the sea hare Aplysia dactylomela. Tetrahedron 2001, 57, 10181-10189. [CrossRef]

62. Kuroda, T.; Kigoshi, H. Aplaminal: A novel cytotoxic aminal isolated from the sea hare Aplysia kurodai. Org. Lett. 2008, 10, 489-491. [CrossRef] [PubMed]

63. Smith, A.B.; Liu, Z. Total synthesis of (-)-aplaminal. Org. Lett. 2008, 10, 4363-4365. [CrossRef] [PubMed]

64. Wang, Z.; Tang, H.; Wang, P.; Gong, W.; Xue, M.; Zhang, H.; Liu, T.; Liu, B.; Yi, Y.; Zhang, W. Bioactive polyoxygenated steroids from the South China Sea Soft Coral, Sarcophyton sp. Mar. Drugs 2013, 11, 775-787. [CrossRef] [PubMed]

65. Yen, W.-H.; Chen, W.-F.; Cheng, C.-H.; Dai, C.-F.; Lu, M.-C.; Su, J.-H.; Su, Y.-D.; Chen, Y.-H.; Chang, Y.-C.; Chen, Y.-H.; et al. A new 5 $\alpha, 8 \alpha$-epidioxysterol from the Soft Coral Sinularia gaweli. Molecules 2013, 18, 2895-2903. [CrossRef] [PubMed]

66. Ahmed, S.; Ibrahim, A.; Arafa, A.S. Anti-H5N1 virus metabolites from the Red Sea soft coral, Sinularia candidula. Tetrahedron Lett. 2013, 54, 2377-2381. [CrossRef]

67. Felder, S.; Kehraus, S.; Neu, E.; Bierbaum, G.; Schaberle, T.F.; Konig, G.M. Salimyxins and enhygrolides: Antibiotic, sponge-related metabolites from the obligate marine myxobacterium Enhygromyxa salina. ChemBioChem 2013, 14, 1363-1371. [CrossRef] [PubMed]

68. Jiménez, C.; Quiñoá, E.; Castedo, L.; Riguera, R. Epidioxy sterols from the tunicates Dendrodoa grossularia and Ascidiella aspersa and the gastropoda Aplysia depilans and Aplysia punctata. J. Nat. Prod. 1986, 49, 905-909. [CrossRef]

69. Yamaguchi, Y.; Nakanishi, Y.; Shimokawa, T.; Hashiguchi, S.; Hayashi, A. Structure elucidation of oxygenated sterols from eggs of sea hare. Aplysia Juliana. Chem. Lett. 1992, 21, 1713-1714. [CrossRef] 
70. Mun, B.; Wang, W.; Kim, H.; Hahn, D.; Yang, I.; Won, D.H.; Kim, E.-H.; Lee, J.; Han, C.; Kim, H.; et al. Cytotoxic $5 \alpha, 8 \alpha$-epidioxy sterols from the marine sponge Monanchora sp. Arch. Pharm. Res. 2015, 38, $18-25$. [CrossRef] [PubMed]

71. Clark, K.E.; Capper, A.; Della Togna, G.; Paul, V.J.; Romero, L.I.; Johns, T.; Cubilla-Rios, L.; Capson, T.L. Ecology- and bioassay-guided drug discovery for treatments of tropical parasitic disease: 5alpha, 8alpha-epidioxycholest-6-en-3beta-ol isolated from the mollusk Dolabrifera dolabrifera shows significant activity against Leishmania donovani. Nat. Prod. Commun. 2013, 8, 1537-1540. [PubMed]

72. Miyamoto, T.; Higuchi, R.; Komori, T.; Fujioka, T.; Mihashi, K. Isolation and structures of aplykurodins A and B, two new isoprenoids from the marine mollusk Aplysia kurodai. Tetrahedron Lett. 1986, 27, 1153-1156. [CrossRef]

73. Spinella, A.; Gavagnin, M.; Crispino, A.; Cimino, G.; Martinez, E.; Ortea, J.; Sodano, G. 4-acetylaplykurodin $\mathrm{B}$ and aplykurodinone $\mathrm{B}$, two ichthyotoxic degraded sterols from the mediterranean mollusk Aplysia fasciata. J. Nat. Prod. 1992, 55, 989-993. [CrossRef] [PubMed]

74. Izzo, I.; Meduri, G.; Avallone, E.; De Riccardis, F.; Sodano, G. Studies towards the synthesis of aplykurodins-Synthesis of 17,18-dihydro-3,9-di-epi-aplykurodinone B. Eur. J. Org. Chem. 2000, 2000, 439-448. [CrossRef]

75. Shoji, N.; Umeyama, A.; Shin, K.; Takeda, K.; Arihara, S.; Kobayashi, J.; Takei, M. Two unique pentacyclic steroids with cis C/D ring junction from Xestospongia bergquistii Fromont, powerful inhibitors of histamine release. J. Org. Chem. 1992, 57, 2996-2997. [CrossRef]

76. Ortega, M.J.; Zubía, E.; Salvá, J. 3-epi-aplykurodinone B, a new degraded sterol from Aplysia fasciata. J. Nat. Prod. 1997, 60, 488-489. [CrossRef] [PubMed]

77. Kawamura, A.; Kita, M.; Kigoshi, H. Aplysiasecosterol A: A 9,11-secosteroid with an unprecedented tricyclic $\gamma$-diketone structure from the sea hare Aplysia kurodai. Angew. Chem. Int. Ed. Engl. 2015, 54, 7073-7076. [CrossRef] [PubMed]

78. Fraga, B.M. Natural sesquiterpenoids. Nat. Prod. Rep. 2010, 27, 1681-1708. [CrossRef] [PubMed]

79. Kamiya, H.; Sakai, R.; Jimbo, M. Bioactive molecules from sea hares. Prog. Mol. Subcell. Biol. 2006, 43, 215-239. [PubMed]

80. Pennings, S.C.; Weiss, A.M.; Paul, V.J. Secondary metabolites of the cyanobacterium Microcoleus lyngbyaceus and the sea hare Stylocheilus longicauda: Palatability and toxicity. Mar. Biol. 1996, 126, 735-743. [CrossRef]

81. Stallard, M.O.; Faulkner, D.J. Chemical constituents of the digestive gland of the sea hare Aplysia californica. II. Importance of diet. Comp. Biochem. Physiol. B. 1974, 49, 37-41. [PubMed]

82. Wessels, M.; Konig, G.M.; Wright, A.D. New natural product isolation and comparison of the secondary metabolite content of three distinct samples of the sea hare Aplysia dactylomela from Tenerife. J. Nat. Prod. 2000, 63, 920-928. [CrossRef] [PubMed]

83. Kusumi, T.; Uchida, H.; Inouye, Y.; Ishitsuka, M.; Yamamoto, H.; Kakisawa, H. Novel cytotoxic monoterpenes having a halogenated tetrahydropyran from Aplysia kurodai. J. Org. Chem. 1987, 52, 4597-4600. [CrossRef]

84. Jung, M.E.; Lew, W. Efficient total synthesis of the cytotoxic halogenated monoterpene aplysiapyranoid D. J. Org. Chem. 1991, 56, 1347-1349. [CrossRef]

85. Jung, M.E.; D'Amico, D.C.; Lew, W. Efficient total synthesis of the cytotoxic halogenated monoterpene aplysiapyranoid A. Tetrahedron Lett. 1993, 34, 923-926. [CrossRef]

86. Jung, M.E.; Fahr, B.T.; D'Amico, D.C. Total syntheses of the cytotoxic marine natural product, aplysiapyranoid C. J. Org. Chem. 1998, 63, 2982-2987. [CrossRef]

87. Grkovic, T.; Appleton, D.R.; Copp, B.R. Chemistry and chemical ecology of some of the common opisthobranch molluscs found on the shores of New Zealand. Chem. N. Z. 2005, 69, 12-15.

88. Stierle, D.B.; Wing, R.M.; Sims, J.J. Marine natural products. Costatone and costatolide, new halogenated monoterpenes from the red seaweed, Plocamium costatum. Tetrahedron Lett. 1976, 17, 4455-4458. [CrossRef]

89. Kazlauskas, R.; Murphy, P.T.; Quinn, R.J.; Wells, R.J.; Schönhlzer, P.; F-Konzern, J.S.; Roche, F.H.-L. Two polyhalogenated monoterpenes from the red alga Plocamium costatum. Tetrahedron Lett. 1976, 17, 4451-4454. [CrossRef]

90. Motti, C.A.; Thomas-Hall, P.; Hagiwara, K.A.; Simmons, C.J.; Willis, R.; Wright, A.D. Accelerated identification of halogenated monoterpenes from Australian specimens of the red algae Plocamium hamatum and Plocamium costatum. J. Nat. Prod. 2014, 77, 1193-1200. [CrossRef] [PubMed] 
91. Williard, P.G.; Grab, L.A. Total synthesis of costatone: A monoterpene from the red seaweed: Plocarnium costatum. Tetrahedron Lett. 1984, 25, 5009-5012. [CrossRef]

92. Quiñoa, E.; Castedo, L.; Riguera, R. The halogenated monoterpenes of Aplysia punctata. A comparative study. Comp. Biochem. Physiol. B 1989, 92, 99-101. [CrossRef]

93. Miyamoto, T.; Higuchi, R.; Marubayashi, N.; Komori1, T. Studies on the constituents of marine opisthobranchia, IV. Two new polyhalogenated monoterpenes from the sea hare Aplysia kurodai. Liebigs Ann. Chem. 1988, 1988, 1191-1193. [CrossRef]

94. Watanabe, K.; Umeda, K.; Kurita, Y.; Takayama, C.; Miyakado, M. Two insecticidal monoterpenes, telfairine and aplysiaterpenoid A, from the red alga Plocamium telfairiae: Structure elucidation, biological activity, and molecular topographical consideration by a semiempirical molecular orbital study. Pestic. Biochem. Physiol. 1990, 37, 275-286. [CrossRef]

95. Faulkner, D.J.; Stallard, M.O. 7-chloro-3,7-dimethyl-1,4,6-tribromo-1-octen-3-ol, a novel monoterpene alcohol from Aplysia californica. Tetrahedron Lett. 1973, 14, 1171-1174. [CrossRef]

96. Katayama, A.; Ina, K.; Nozaki, H.; Nakayama, M. Structural elucidation of kurodainol, a novel halogenated monoterpene from sea hare Aplysia Kurodai. Agric. Biol. Chem. 1982, 46, 859-860. [CrossRef]

97. Ortega, M.J.; Zubía, E.; Salvá, J. New polyhalogenated monoterpenes from the sea hare Aplysia punctata. J. Nat. Prod. 1997, 60, 482-484. [CrossRef] [PubMed]

98. Conolly, J.D.; Hill, R.A. Mono and sesquiterpenoids. In Dictionary of Terpenoids, 1st ed.; Champman and Hall: London, UK, 1991; Volume 1, pp. 1-153.

99. Dias, T.; Brito, I.; Moujir, L.; Paiz, N.; Darias, J.; Cueto, M. Cytotoxic sesquiterpenes from Aplysia dactylomela. J. Nat. Prod. 2005, 68, 1677-1679. [CrossRef] [PubMed]

100. Desoti, V.C.; Lazarin-Bidóia, D.; Sudatti, D.B.; Pereira, R.C.; Alonso, A.; Ueda-Nakamura, T.; Dias Filho, B.P.; Nakamura, C.V.; De Silva, S.O. Trypanocidal action of (-)-elatol involves an oxidative stress triggered by mitochondria dysfunction. Mar. Drugs 2012, 10, 1631-1646. [CrossRef] [PubMed]

101. Dos Santos, A.O.; Veiga-Santos, P.; Ueda-Nakamura, T.; Dias Filho, B.P.; Sudatti, D.B.; Bianco, É.M.; Pereira, R.C.; Nakamura, C.V. Effect of elatol, isolated from red seaweed Laurencia dendroidea, on Leishmania amazonensis. Mar. Drugs 2010, 8, 2733-2743. [CrossRef] [PubMed]

102. Campos, A.; Souza, C.B.; Lhullier, C.; Falkenberg, M.; Schenkel, E.P.; Ribeiro-Do-Valle, R.M.; Siqueira, J.M. Anti-tumor effects of elatol, a marine derivative compound obtained from red algae Laurencia microcladia. J. Pharm. Pharmacol. 2012, 64, 1146-1154. [CrossRef] [PubMed]

103. Vairappan, C.S.; Daitoh, M.; Suzuki, M.; Abe, T.; Masuda, M. Antibacterial halogenated metabolites from the Malaysian Laurencia species. Phytochemistry 2001, 58, 291-297. [CrossRef]

104. Bianco, E.M.; Pires, L.; Santos, G.K.N.; Dutra, K.A.; Reis, T.N.V.; Vasconcelos, E.R.T.P.P.; Cocentino, A.L.M.; Navarro, D.M.A.F. Larvicidal activity of seaweeds from northeastern Brazil and of a halogenated sesquiterpene against the dengue mosquito (Aedes aegypti). Ind. Crops Prod. 2013, 43, 270-275. [CrossRef]

105. Desoti, V.C.; Lazarin-Bidóia, D.; Sudatti, D.B.; Pereira, R.C.; Ueda-Nakamura, T.; Nakamura, C.V.; de Oliveira Silva, S. Additional evidence of the trypanocidal action of (-)-elatol on amastigote forms through the involvement of reactive oxygen species. Mar. Drugs 2014, 12, 4973-4983. [CrossRef] [PubMed]

106. König, G.M.; Wright, A.D. Laurencia rigida: Chemical investigations of its antifouling dichloromethane extract. J. Nat. Prod. 1997, 60, 967-970. [CrossRef] [PubMed]

107. Vairappan, C.S.; Anangdan, S.P.; Matsunaga, S. Diet-derived halogenated metabolite from the sea hare Aplysia parvula. Malays. J. Sci. 2009, 28, 269-273.

108. Díaz-Marrero, A.R.; De La Rosa, J.M.; Brito, I.; Darias, J.; Cueto, M. Dactylomelatriol, a biogenetically intriguing omphalane-derived marine sesquiterpene. J. Nat. Prod. 2012, 75, 115-118. [CrossRef] [PubMed]

109. Vairappan, C.S. Potent antibacterial activity of halogenated metabolites from Malaysian red algae, Laurencia majuscula (Rhodomelaceae, Ceramiales). Biomol. Eng. 2003, 20, 255-259. [CrossRef]

110. Da Silva Machado, F.L.; Pacienza-Lima, W.; Rossi-Bergmann, B.; De Souza Gestinari, L.M.; Fujii, M.T.; Campos De Paula, J.; Costa, S.S.; Lopes, N.P.; Kaiser, C.R.; Soares, A.R. Antileishmanial sesquiterpenes from the Brazilian red alga Laurencia dendroidea. Planta Med. 2011, 77, 733-735. [CrossRef] [PubMed]

111. Hegazy, M.-E.F.; Moustfa, A.Y.; Mohamed, A.E.-H.H.; Alhammady, M.A.; Elbehairi, S.E.I.; Ohta, S.; Paré, P.W. New cytotoxic halogenated sesquiterpenes from the Egyptian sea hare, Aplysia oculifera. Tetrahedron Lett. 2014, 55, 1711-1714. [CrossRef] 
112. Kaiser, C.R.; Pitombo, L.F.; Pinto, A.C. C-13 and H-1 NMR assignments of the chamigrenes prepacifenol and dehydroxyprepacifenol epoxides. Spectrosc. Lett. 1998, 31, 573-585. [CrossRef]

113. Ireland, C.; Stallard, M.O.; Faulkner, D.J.; Finer, J.; Clardy, J. Some chemical constituents of the digestive gland of the sea hare Aplysia californica. J. Org. Chem. 1976, 41, 2461-2465. [CrossRef] [PubMed]

114. Faulkner, D.J.; Stallard, M.O.; Ireland, C. Prefacifenol epoxide, a halogenated sesquiterpene diepoxide. Tetrahedron Lett. 1974, 15, 3571-3574. [CrossRef]

115. Pitombo, L.F.; Kaiser, C.R.; Pinto, A.C. Occurrence of chamigrenes in Aplysia dactylomela from Brazilian waters. Bol. Soc. Chil. Quim. 1996, 41, 433-436.

116. Sims, J.J.; Fenical, W.; Wing, R.M.; Radlick, P. Marine natural products. I. Pacifenol, a rare sesquiterpene containing bromine and chlorine from the red alga, Laurencia pacifica. J. Am. Chem. Soc. 1971, 93, 3774-3775. [CrossRef]

117. Kaiser, C.R.; Pitombo, L.F.; Pinto, A.C. Complete ${ }^{1} \mathrm{H}$ and ${ }^{13} \mathrm{C}$ NMR assignments of chamigrenes from Aplysia dactylomela. Magn. Reson. Chem. 2001, 39, 147-149. [CrossRef]

118. San-Martín, A.; Rovirosa, J.; Astudillo, L.; Sepulveda, B.; Ruiz, D.; San-Martin, C. Biotransformation of the marine sesquiterpene pacifenol by a facultative marine fungus. Nat. Prod. Res. 2008, 22, 1627-1632. [CrossRef] [PubMed]

119. Jongaramruong, J.; Blackman, A.J.; Skelton, B.W.; White, A.H. Chemical relationships between the sea hare Aplysia parvula and the red seaweed Laurencia filiformis from Tasmania. Aust. J. Chem. 2002, 55, 275-280. [CrossRef]

120. Gil, B.; Ferrándiz, M.L.; Sanz, M.J.; Terencio, M.C.; Ubeda, A.; Rovirosa, J.; San-Martin, A.; Alcaraz, M.J.; Payá, M. Inhibition of inflammatory responses by epitaondiol and other marine natural products. Life Sci. 1995, 57, 25-30. [CrossRef]

121. Pietra, F. Evolution of the secondary metabolite versus evolution of the species. Pure Appl. Chem. 2003, 74, 2207-2211. [CrossRef]

122. McPhail, K.L.; Davies-Coleman, M.T.; Copley, R.C.B.; Eggleston, D.S. New halogenated sesquiterpenes from South African specimens of the circumtropical sea hare Aplysia dactylomela. J. Nat. Prod. 1999, 62, 1618-1623. [CrossRef]

123. Kimura, J; Kamada, N.; Tsujimoto, Y. Fourteen chamigrane derivatives from a red alga, Laurencia nidifica. Bull. Chem. Soc. Jpn. 1999, 72, 289-292. [CrossRef]

124. Fraga, B.M. Natural sesquiterpenoids. Nat. Prod. Rep. 1997, 14, 145-162. [CrossRef]

125. González, A.G.; Darias, J.; Estèvez, E. Chemotherapeutic activity of polyhalogenated terpenes from Spanish algae. Planta Med. 1982, 44, 44-46. [CrossRef] [PubMed]

126. Gross, H.; Konig, G.M. Terpenoids from marine organisms: Unique structures and their pharmacological potential. Phytochem. Rev. 2006, 5, 115-141. [CrossRef]

127. Lhullier, C.; Falkenberg, M.; Ioannou, E.; Quesada, A.; Papazafiri, P.; Horta, P.A.; Schenkel, E.P.; Vagias, C.; Roussis, V. Cytotoxic halogenated metabolites from the Brazilian red alga Laurencia catarinensis. J. Nat. Prod. 2010, 73, 27-32. [CrossRef] [PubMed]

128. Brito, I.; Dias, T.; Díaz-Marrero, A.R.; Darias, J.; Cueto, M. Aplysiadiol from Aplysia dactylomela suggested a key intermediate for a unified biogenesis of regular and irregular marine algal bisabolene-type metabolites. Tetrahedron 2006, 62, 9655-9660. [CrossRef]

129. Hollenbeak, K.H.; Schmitz, F.J.; Hossain, M.B.; Van Der Helm, D. Deodactol, antineoplastic sesquiterpenoid from the sea hare Aplysia dactylomela. Tetrahedron 1979, 35, 541-545. [CrossRef]

130. Harinantenaina, L.; Kurata, R.; Asakawa, Y. Chemical constituents of Malagasy liverworts, part III: Sesquiterpenoids from Bazzania decrescens and Bazzania madagassa. Chem. Pharm. Bull. 2005, 53, 515-518. [CrossRef] [PubMed]

131. Guella, G.; Öztunç, A.; Mancini, I.; Pietra, F. Stereochemical features of sesquiterpene metabolites as a distinctive trait of red seaweeds in the genus Laurencia. Tetrahedron Lett. 1997, 38, 8261-8264. [CrossRef]

132. Ichiba, T.; Higa, T. New cuparene-derived sesquiterpenes with unprecedented oxygenation pattern from the sea hare Aplysia dactylomela. J. Org. Chem. 1986, 51, 3364-3366. [CrossRef]

133. Vairappan, C.S.; Ishii, T.; Lee, T.K.; Suzuki, M.; Zhaoqi, Z. Antibacterial activities of a new brominated diterpene from Borneon Laurencia spp. Mar. Drugs 2010, 8, 1743-1749. [CrossRef] [PubMed]

134. Tsukamoto, S.; Yamashita, Y.; Ohta, T. New cytotoxic and antibacterial compounds isolated from the sea hare, Aplysia kurodai. Mar. Drugs 2005, 3, 22-28. [CrossRef] 
135. Kim, M.M.; Mendis, E.; Kim, S.K. Laurencia okamurai extract containing laurinterol induces apoptosis in melanoma cells. J. Med. Food 2008, 11, 260-266. [CrossRef] [PubMed]

136. Liu, Y.; Liang, H.; Su, A.; He, J.; Yu, H. Effect of aplysin on the proliferation and apoptosis in human gastric cancer cell SGC-7901. Chin. Pharmacol. Bull. 2010, 26, 333-337.

137. Gong, A.; Ge, N.; Yao, W.; Lu, L.; Liang, H. Aplysin enhances temozolomide sensitivity in glioma cells by increasing miR-181 level. Cancer Chemother. Pharmacol. 2014, 74, 531-538. [CrossRef] [PubMed]

138. Gong, A.-J.; Gong, L.-L.; Yao, W.-C.; Ge, N.; Lu, L.-X.; Liang, H. Aplysin induces apoptosis in glioma cells through HSP90/AKT pathway. Exp. Biol. Med. 2015, 240, 639-644. [CrossRef] [PubMed]

139. Ge, N.; Liang, H.; Liu, Y.; Ma, A.-G.; Han, L. Protective effect of aplysin on hepatic injury in ethanol-treated rats. Food Chem. Toxicol. 2013, 62, 361-372. [CrossRef] [PubMed]

140. Copley, R.C.; Davies-Coleman, M.T.; Edmonds, D.R.; Faulkner, D.J.; McPhail, K.L. Absolute stereochemistry of ibhayinol from a South African sea hare. J. Nat. Prod. 2002, 65, 580-582. [CrossRef] [PubMed]

141. König, G.M.; Wright, A.D. Sesquiterpene content of the antibacterial dichloromethane extract of the marine red alga Laurencia obtusa. Planta Med. 1997, 63, 186-187. [CrossRef] [PubMed]

142. Blunt, J.W.; Lake, R.J.; Munro, M.H.G. Sesquiterpenes from the marine red alga Laurencia distichophylla. Phytochemistry 1984, 23, 1951-1954. [CrossRef]

143. Gewali, M.B.; Ronald, R.C. Synthesis of allolaurinterol. J. Org. Chem. 1982, 47, 2792-2795. [CrossRef]

144. Stallard, M.O.; Fenical, W.; Kittredge, J.S. The brasilenols, rearranged sesquiterpene alcohols isolated from the marine opisthobranch Aplysia brasiliana. Tetrahedron 1978, 34, 2077-2081. [CrossRef]

145. Tori, M.; Nakashima, K.; Asakawa, Y. Sesquiterpenes and a phenolic compound from the liverwort Omphalanthus filiformis. Phytochemistry 1995, 38, 651-653. [CrossRef]

146. Dieter, R.K.; Kinnel, R.; Meinwald, J.; Eisner, T. Brasudol and isobrasudol: Two bromosesquiterpenes from a sea hare Aplysia brasiliana. Tetrahedron Lett. 1979, 20, 1645-1648. [CrossRef]

147. Brennan, M.R.; Erickson, K.L. Austradiol acetate and austradiol diacetate, 4,6-dihydroxy-(+)-selinane derivatives from an Australian Laurencia sp. J. Org. Chem. 1982, 47, 3917-3921. [CrossRef]

148. Sun, H.H.; Waraszkiewicz, S.M.; Erickson, K.L. Sesquiterpenoid alcohols from the Hawaiian marine alga Laurencia nidifica. Tetrahedron Lett. 1976, 17, 585-588. [CrossRef]

149. Suzuki, T.; Kikuchi, H.; Kurosawa, E. Six new sesquiterpenoids from the red alga Laurencia nipponica Yamada. Bull. Chem. Soc. Jpn. 1982, 55, 1561-1563. [CrossRef]

150. Baker, B.; Ratnapala, L.; Mahindaratne, M.P.D.; de Silva, E.D.; Tillekeratne, L.M.V.; Jeong, J.H.; Scheuer, P.J.; Seff, K. Lankalapuol A and B: Two cis-eudesmanes from the sea hare Aplysia dactylomela. Tetrahedron 1988, 44, 4695-4701. [CrossRef]

151. Vairappan, C.S.; Anangdan, S.P.; Lee, T.K. Additional halogenated secondary metabolites from the sea hare Aplysia dactylomela. Malays. J. Sci. 2007, 26, 57-64.

152. Pettit, G.R.; Herald, C.L.; Allen, M.S.; von Dreele, R.B.; Vanell, L.D.; Kao, J.P.; Blake, W. The isolation and structure of aplysistatin. J. Am. Chem. Soc. 1977, 99, 262-263. [CrossRef] [PubMed]

153. Rogers, C.N.; de Nys, R.; Steinberg, P.D. Effects of algal diet on the performance and susceptibility to predation of the sea hare Aplysia parvula. Mar. Ecol. Prog. Ser. 2002, 236, 241-254. [CrossRef]

154. Vairappan, C.S.; Kamada, T.; Lee, W.-W.; Jeon, Y.-J. Anti-inflammatory activity of halogenated secondary metabolites of Laurencia snackeyi (Weber-van Bosse) Masuda in LPS-stimulated RAW 264.7 macrophages. J. Appl. Phycol. 2013, 25, 1805-1813. [CrossRef]

155. Matsuda, H.; Tomiie, Y.; Yamamura, S.; Hirata, Y. The structure of aplysin-20. Chem. Commun. (Lond.) 1967, 17,898b-899b. [CrossRef]

156. Ojika, M.; Yoshida, Y.; Okumura, M.; Ieda, S.; Yamada, K. Aplysiadiol, a new brominated diterpene from the marine mollusc Aplysia kurodai. J. Nat. Prod. 1990, 53, 1619-1622. [CrossRef]

157. Takahashi, Y.; Suzuki, M.; Abe, T.; Masuda, M. Anhydroaplysiadiol from Laurencia japonensis. Phytochemistry 1998, 48, 987-990. [CrossRef]

158. Ojika, M.; Kigoshi, H.; Yoshikawa, K.; Yamada, K. A new bromo diterpene, epi-aplysin-20, and ent-isoconcinndiol from the marine mollusc Aplysia kurodai. Bull. Chem. Soc. Jpn. 1992, 65, 2300-2302. [CrossRef]

159. Midland, S.L.; Wing, R.M.; Sims, J.J. New crenulides from the sea hare Aplysia vaccaria. J. Org. Chem. 1983, 48, 1906-1909. [CrossRef] 
160. Sun, H.H.; McEnroe, F.J.; Fenical, W. Acetoxycrenulide, a new bicyclic cyclopropane-containing diterpenoid from the brown seaweed Dictyota crenulata. J. Org. Chem. 1983, 48, 1903-1906. [CrossRef]

161. Othmani, A.; Bouzidi, N.; Viano, Y.; Alliche, Z.; Seridi, H.; Blache, Y.; El Hatta, M.; Briand, J.-F.; Culioli, G. Anti-microfouling properties of compounds isolated from several Mediterranean Dictyota spp. J. Appl. Phycol. 2014, 26, 1573-1584. [CrossRef]

162. Bouaicha, N.; Pesando, D.; Puel, D.; Tringali, C. Cytotoxic diterpenoids from the brown alga Dilophus ligulatus. J. Nat. Prod. 1993, 56, 1747-1752. [CrossRef] [PubMed]

163. Ko, R.K.; Kang, M.C.; Kim, S.S.; Oh, T.H.; Kim, G.O.; Hyun, C.G.; Hyun, J.W.; Lee, N.H. Anti-melanogenesis constituents from the seaweed Dictyota coriacea. Nat. Prod. Commun. 2013, 8, 427-428. [PubMed]

164. Estrada, D.M.; Ravelo, J.L.; Ruiz-Pérez, C.; Martín, J.D.; Solans, X. Dactylomelol, a new class of diterpene from the sea hare Aplysia dactylomela. Tetrahedron Lett. 1989, 30, 6219-6220. [CrossRef]

165. Fernández, J.J.; Souto, M.L.; Gil, L.V.; Norte, M. Isolation of naturally occurring dactylomelane metabolites as Laurencia constituents. Tetrahedron 2005, 61, 8910-8915. [CrossRef]

166. Schmitz, F.J.; Michaud, D.P.; Schmidt, P.G. Marine natural products: Parguerol, deoxyparguerol, and isoparguerol. New brominated diterpenes with modified pimarane skeletons from the sea hare Aplysia dactylomela. J. Am. Chem. Soc. 1982, 104, 6415-6423. [CrossRef]

167. Tsukamoto, S.; Yamashita, Y.; Yoshida, T.; Ohta, T. Parguerol and isoparguerol isolated from the sea hare, Aplysia kurodai, induce neurite outgrowth in PC-12 Cells. Mar. Drugs 2004, 2, 170-175. [CrossRef]

168. Awad, N.E. Bioactive brominated diterpenes from the marine red alga Jania rubens (L.) Lamx. Phytother. Res. 2004, 18, 275-279. [CrossRef] [PubMed]

169. Pettit, G.R.; Herald, C.L.; Einck, J.J.; Vanell, L.D.; Brown, P.; Gust, D. Isolation and structure of angasiol. J. Org. Chem. 1978, 43, 4685-4686. [CrossRef]

170. Atta-Ur-Rahmanc; Alvi, K.A.; Abbas, S.A.; Sultana, T.; Shameel, M.; Iqbal Choudhary, M.; Clardy, J.C. A diterpenoid lactone from Aplysia Juliana. J. Nat. Prod. 1991, 54, 886-888. [CrossRef]

171. Jiménez-Romero, C.; Mayer, A.M.S.; Rodríguez, A.D. Dactyloditerpenol acetate, a new prenylbisabolane-type diterpene from Aplysia dactylomela with significant in vitro anti-neuroinflammatory activity. Bioorg. Med. Chem. Lett. 2014, 24, 344-348. [CrossRef] [PubMed]

172. Mayer, A.M.S. Therapeutic implications of microglia activation by lipopolysaccharide and reactive oxygen species generation in septic shock and central nervous system pathologies: A review. Medicina 1998, 58, 377-385. [PubMed]

173. Kim, S.-K.; Himaya, S.W.A. Triterpene glycosides from sea cucumbers and their biological activities. Adv. Food Nutr. Res. 2012, 65, 297-319. [PubMed]

174. Sultana, N.; Saify, Z.S. Naturally occurring and synthetic agents as potential anti-inflammatory and immunomodulants. Antiinflamm. Antiallergy Agents Med. Chem. 2012, 11, 3-19. [CrossRef] [PubMed]

175. Tang, S.-A.; Zhou, Q.; Guo, W.-Z.; Qiu, Y.; Wang, R.; Jin, M.; Zhang, W.; Li, K.; Yamori, T.; Dan, S.; et al. In vitro antitumor activity of stellettin $\mathrm{B}$, a triterpene from marine sponge Jaspis stellifera, on human glioblastoma cancer SF295 cells. Mar. Drugs 2014, 12, 4200-4213. [CrossRef] [PubMed]

176. Akl, M.R.; Foudah, A.I.; Ebrahim, H.Y.; Meyer, S.A.; El Sayed, K.A. The marine-derived sipholenol A-4-O-3', $4^{\prime}$-dichlorobenzoate inhibits breast cancer growth and motility in vitro and in vivo through the suppression of Brk and FAK signaling. Mar. Drugs 2014, 12, 2282-2304. [CrossRef] [PubMed]

177. Li, Y.; Tang, H.; Tian, X.; Lin, H.; Wang, M.; Yao, M. Three new cytotoxic isomalabaricane triterpenes from the marine sponge Stelletta tenuis. Fitoterapia 2015, 106, 226-230. [CrossRef] [PubMed]

178. Manzo, E.; Gavagnin, M.; Bifulco, G.; Cimino, P.; Di Micco, S.; Ciavatta, M.L.; Guo, Y.W.; Cimino, G. Aplysiols $\mathrm{A}$ and $\mathrm{B}$, squalene-derived polyethers from the mantle of the sea hare Aplysia dactylomela. Tetrahedron 2007, 63, 9970-9978. [CrossRef]

179. Vera, B.; Rodríguez, A.D.; Avilés, E.; Ishikawa, Y. Aplysqualenols A and B: Squalene-derived polyethers with antitumoral and antiviral activity from the Caribbean Sea slug Aplysia dactylomela. Eur. J. Org. Chem. 2009, 2009, 5327-5336. [CrossRef] [PubMed]

180. Ola, A.R.B.; Babey, A.M.; Motti, C.; Bowden, B.F. Aplysiols CE, brominated triterpene polyethers from the marine alga Chondria armata and a revision of the structure of aplysiol B. Aust. J. Chem. 2010, 63, 907-914. [CrossRef] 
181. Cen-Pacheco, F.; Mollinedo, F.; Villa-Pulgarín, J.A.; Norte, M.; Fernández, J.J.; Daranas, A.H. Saiyacenols A and B: The key to solve the controversy about the configuration of aplysiols. Tetrahedron 2012, 68, 7275-7279. [CrossRef]

182. Blunt, J.W.; Hartshorn, M.P.; McLennan, T.J.; Munro, M.H.G.; Robinson, W.T.; Yorke, S.C. Thyrsiferol: A squalene-derived metabolite of Laurencia thyrsifera. Tetrahedron Lett. 1978, 19, 69-72. [CrossRef]

183. Sakemi, S.; Higa, T.; Jefford, C.W.; Bernardinelli, G. Venustatriol. A new, anti-viral, triterpene tetracyclic ether from Laurencia venusta. Tetrahedron Lett. 1986, 27, 4287-4290. [CrossRef]

184. Fernández, J.J.; Souto, M.L.; Norte, M. Evaluation of the cytotoxic activity of polyethers isolated from Laurencia. Bioorg. Med. Chem. 1998, 6, 2237-2243. [CrossRef]

185. Little, R.D.; Nishiguchi, G.A. Synthetic efforts toward, and biological activity of, thyrsiferol and structurally-related analogues. Stud. Nat. Prod. Chem. 2008, 35, 3-56.

186. Mahdi, F.; Falkenberg, M.; Ioannou, E.; Roussis, V.; Zhou, Y.-D.; Nagle, D.G. Thyrsiferol inhibits mitochondrial respiration and HIF-1 activation. Phytochem. Lett. 2011, 4, 75-78. [CrossRef] [PubMed]

187. Poddar, M.; Aminabhavi, T.M.; Patel, M.; Singh, N.; Noolvi, M.N. HIF inhibitors: New hope for cancer therapy. Lett. Drug Des. Discov. 2015, 12, 736-753. [CrossRef]

188. González, I.C.; Forsyth, C.J. Total synthesis of thyrsiferyl 23-acetate, a specific inhibitor of protein phosphatase 2A and an anti-leukemic inducer of apoptosis. J. Am. Chem. Soc. 2000, 122, 9099-9108. [CrossRef]

189. Janssens, V.; Goris, J. Protein phosphatase 2A: A highly regulated family of serine/threonine phosphatases implicated in cell growth and signalling. Biochem. J. 2001, 353, 417-439. [CrossRef] [PubMed]

190. Kuniyoshi, M.; Yamada, K.; Higa, T. A biologically active diphenyl ether from the green alga Cladophora fascicularis. Experientia 1985, 41, 523-524. [CrossRef]

191. Kamio, M.; Nguyen, L.; Yaldiz, S.; Derby, C.D. How to produce a chemical defense: Structural elucidation and anatomical distribution of aplysioviolin and phycoerythrobilin in the sea hare Aplysia californica. Chem. Biodivers. 2010, 7, 1183-1197. [CrossRef] [PubMed]

192. Kamio, M.; Grimes, T.V.; Hutchins, M.H.; van Dam, R.; Derby, C.D. The purple pigment aplysioviolin in sea hare ink deters predatory blue crabs through their chemical senses. Anim. Behav. 2010, 80, 89-100. [CrossRef]

193. Sakai, S.; Komura, Y.; Nishimura, Y.; Sugawara, T.; Hirata, T. Inhibition of mast cell degranulation by phycoerythrin and its pigment moiety phycoerythrobilin, prepared from Porphyra yezoensis. Food Sci. Technol. Res. 2011, 17, 171-177. [CrossRef]

194. Przeslawski, R.; Benkendorff, K.; Davis, A.R. A quantitative survey of mycosporine-like amino acids (MAAS) in intertidal egg masses from temperate rocky shores. J. Chem. Ecol. 2005, 31, 2417-2438. [CrossRef] [PubMed]

195. Kamio, M.; Kicklighter, C.E.; Nguyen, L.; Germann, M.W.; Derby, C.D. Isolation and structural elucidation of novel mycosporine-like amino acids as alarm cues in the defensive ink secretion of the sea hare Aplysia californica. Helv. Chim. Acta 2011, 94, 1012-1018. [CrossRef]

196. Singh, S.P.; Kumari, S.; Rastogi, R.P.; Singh, K.L.; Sinha, R.P. Mycosporine-like amino acids (MAAs): Chemical structure, biosynthesis and significance as UV-absorbing/screening compounds. Indian J. Exp. Biol. 2008, 46, 7-17. [PubMed]

197. Kicklighter, C.E.; Kamio, M.; Nguyen, L.; Germann, M.W.; Derby, C.D. Mycosporine-like amino acids are multifunctional molecules in sea hares and their marine community. Proc. Natl. Acad. Sci. USA 2011, 108, 11494-11499. [CrossRef] [PubMed]

198. Cubillos, V.M.; Burritt, D.J.; Lamare, M.D.; Peake, B.M. The relationship between UV-irradiance, photoprotective compounds and DNA damage in two intertidal invertebrates with contrasting mobility characteristics. J. Photochem. Photobiol. B 2015, 149, 280-288. [CrossRef] [PubMed]

199. Fernandes, S.C.M.; Alonso-Varona, A.; Palomares, T.; Zubillaga, V.; Labidi, J.; Bulone, V. Exploiting mycosporines as natural molecular sunscreens for the fabrication of UV-absorbing green materials. ACS Appl. Mater. Interfaces 2015, 7, 16558-16564. [CrossRef] [PubMed]

200. Colabella, F; Moliné, M.; Libkind, D. UV sunscreens of microbial origin: Mycosporines and mycosporine-like aminoacids. Recent Pat. Biotechnol. 2015, 8, 179-193. [CrossRef]

201. Carefoot, T.H.; Harris, M.; Taylor, B.E.; Donovan, D.; Karentz, D. Mycosporine-like amino acids: Possible UV protection in eggs of the sea hare Aplysia dactylomela. Mar. Biol. 1998, 130, 389-396. [CrossRef] 
202. Carefoot, T.H.; Karentz, D.; Pennings, S.C.; Young, C.L. Distribution of mycosporine-like amino acids in the sea hare Aplysia dactylomela: Effect of diet on amounts and types sequestered over time in tissues and spawn. Comp. Biochem. Physiol. C Toxicol. Pharmacol. 2000, 126, 91-104. [CrossRef]

203. De La Coba, F.; Aguilera, J.; Figueroa, F.L.; De Gálvez, M.V.; Herrera, E. Antioxidant activity of mycosporine-like amino acids isolated from three red macroalgae and one marine lichen. J. Appl. Phycol. 2009, 21, 161-169. [CrossRef]

204. Andreguetti, D.; Stein, E.M.; Pereira, C.M.; Pinto, E.; Colepicolo, P. Antioxidant properties and UV absorbance pattern of mycosporine-like amino acids analogs synthesized in an environmentally friendly manner. J. Biochem. Mol. Toxicol. 2013, 27, 305-312. [CrossRef] [PubMed]

205. Khosravi, S.; Khodabandeh, S.; Agh, N.; Bakhtiarian, M. Effects of salinity and ultraviolet radiation on the bioaccumulation of mycosporine-like amino acids in Artemia from Lake Urmia. Photochem. Photobiol. 2013, 89, 400-405. [CrossRef] [PubMed]

206. Ojika, M.; Yoshida, Y.; Nakayama, Y.; Yamada, K. Aplydilactone, a novel fatty acid metabolite from the marine mollusc Aplysia kurodai. Tetrahedron Lett. 1990, 31, 4907-4910. [CrossRef]

207. Yamada, K.; Kigoshi, H. Bioactive compounds from the sea hares of two genera: Aplysia and Dolabella. Bull. Chem. Soc. Jpn. 1997, 70, 1479-1489. [CrossRef]

(C) 2016 by the authors; licensee MDPI, Basel, Switzerland. This article is an open access article distributed under the terms and conditions of the Creative Commons by Attribution (CC-BY) license (http:/ / creativecommons.org/licenses/by/4.0/). 